
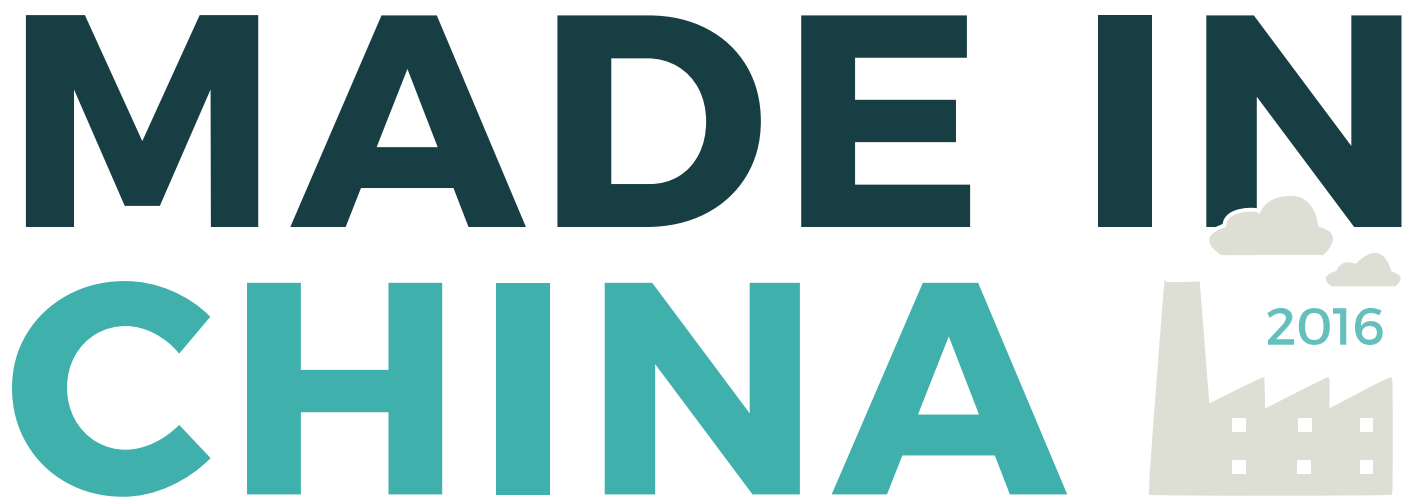

2016

A Quarterly on Chinese Labour, Civil Society, and Rights

ISSUE 4, 2016

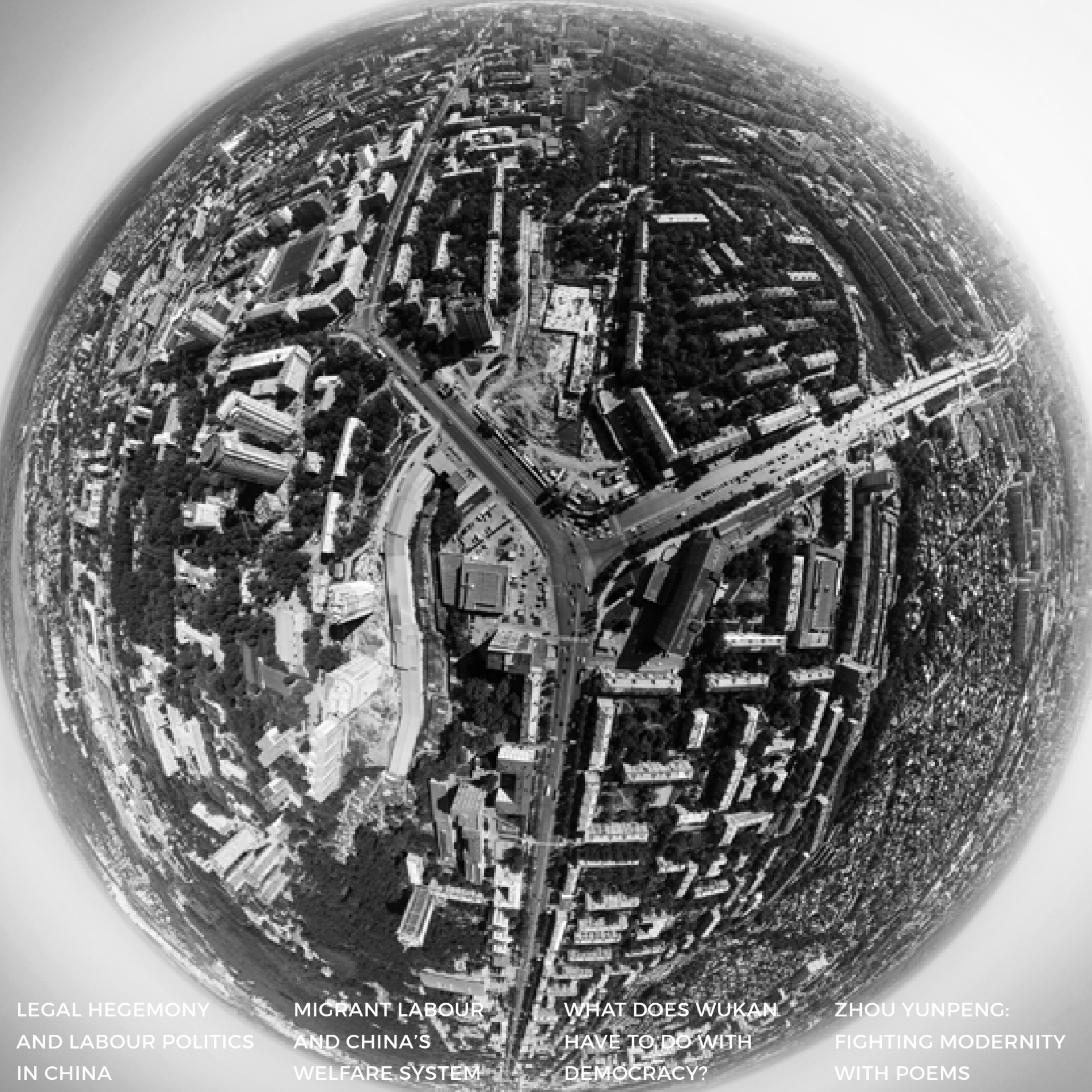

Elaine Sio-ieng Hui

Ivan Franceschini 


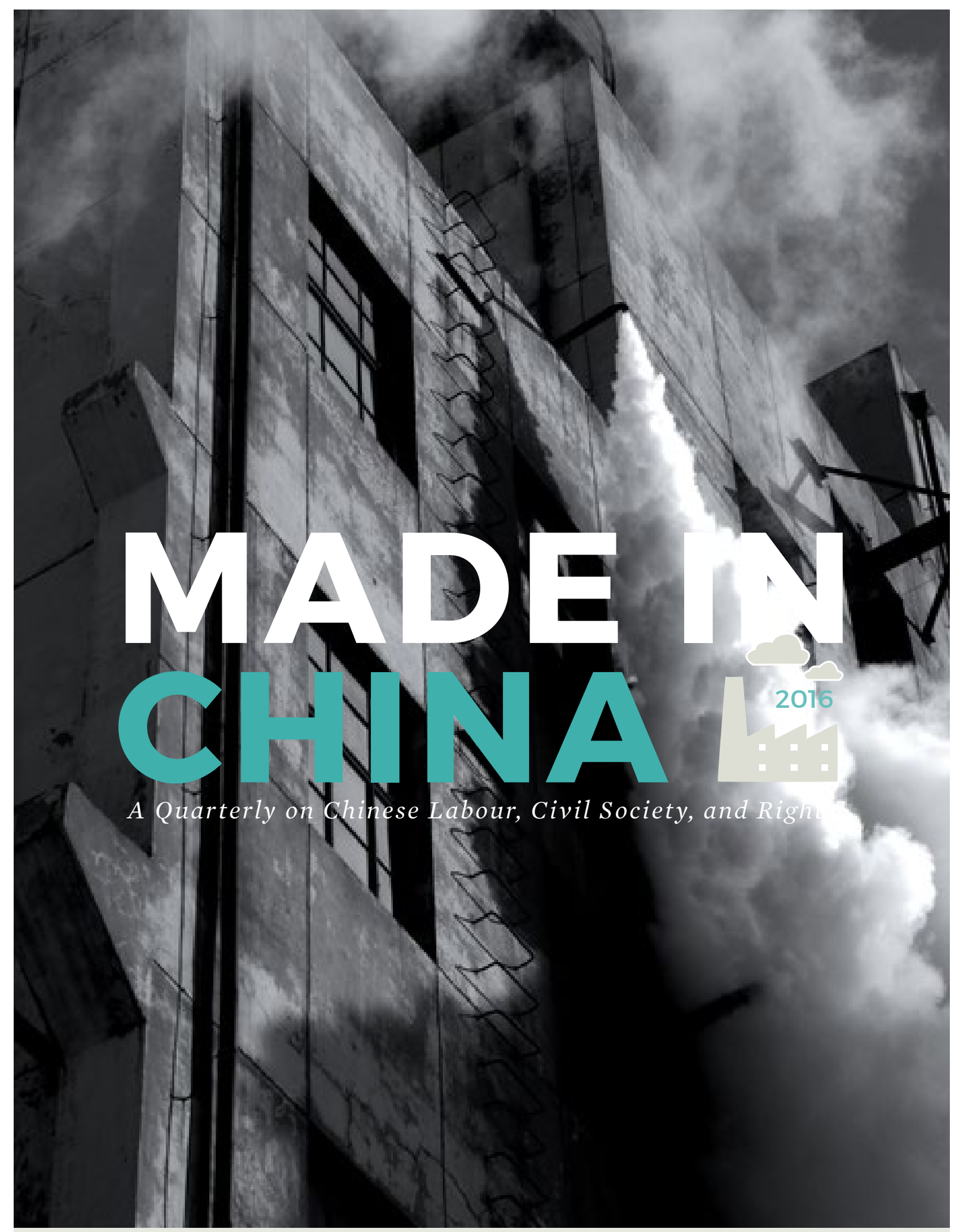

Made in China

Made in China is a quarterly on Chinese labour, civil society, and rights. This project has been produced with the financial assistance of the Australian Centre on China in the World (CIW). Australian National University, and the European Union Horizon 2020 research and innovation programme under the Marie Skłodowska-Curie grant agreement No 654852. The views expressed are those of the individual authors and do not represent the views of the European Union, CIW, 


\section{6}

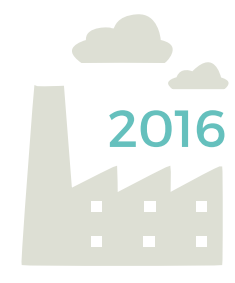

ISSUE \#4

OCTOBER-DECEMBER 2016

ISSN 2206-9119

\section{EDITORS}

Ivan Franceschini

Kevin Lin

Nicholas Loubere

COPY-EDITING

Sharon Strange

ART DIRECTION

Tommaso Facchin

ISSUE CONTRIBUTORS

Beatriz Carrillo

Anita Chan

Mingwei Liu

Elaine Sio-ieng Hui

Kaxton Siu

Sarah Swider

Luigi Tomba

\section{PHOTO CREDITS}

Alexandr Markin (cover) 123RF

Adam He (PP. 9-10) Flickr

Peijin Chen (PP.15-18) Flickr

Paz Lee (P.19) Flickr

Ben Stassen (P.23) Flickr

Liu Jiuming (P.32) 123RF

Tommaso Bonaventura (P.33) Web

中 童 全球研究中心

AUSTRALIAN CENTRE ON CHINA IN THE WORLD

TABLE OF CONTENTS

EDITORIAL (P.5)

EYE IN THE SKY

Ivan Franceschini

Kevin Lin

Nicholas Loubere

BRIEFS (P.6)

CHINA COLUMNS (P.9)

THE NEGLECTED SIDE OF

THE COIN (P.11)

Elaine Sio-ieng Hui

MIGRANT LABOUR AND

THE SUSTAINABILITY OF

CHINA'S WELFARE SYSTEM

(P.15)

Beatriz Carrillo

WHAT DOES WUKAN HAVE

TO DO WITH DEMOCRACY? (P.19)

Luigi Tomba

\section{FORUM (P.23)}

INTERPRETING

CHINESE LABOUR:

INFORMALISATION OR

EMPOWERMENT?

Anita Chan

Kaxton Siu

Sarah Swider

WORK OF ARTS (P.32)

THE COW AND THE GOAT DESCEND THE MOUNTAIN: FIGHTING MODERNITY WITH POEMS (p.33)

Ivan Franceschini

\section{ACADEMIC WATCH (P.37)}

MINGWEI LIU ON CHINA AT WORK (P.37)
CHINORESIE

mismatched shards of China 


\section{WHY MADE IN CHINA?}

In the last few years, the Chinese labour movement has witnessed significant developments, not only with the occurrence of some of the largest strikes in decades but also the emergence of grave challenges for workers and activists. Made in China springs from the belief that this calls for more serious analysis from both scholars and practitioners, as well for a critical engagement with a broader international audience interested in forging international solidarity. 


\section{EYE IN THE SKY \\ Views on State Control in China}

To wrap up a tumultuous year in Chinese labour and civil society, we are pleased to announce the publication of the fourth issue of Made in China. Among the most notable events in the last quarter are the protests that erupted at several plants in China owned by multinational companies, such as Coca-Cola, Danone, and Sony, following the announcement that the factories would be sold to local Chinese companies. Other significant happenings include a series of blasts at Chinese coal mines that claimed dozens of lives and prompted widespread public questioning of the commitment of the authorities to workplace safety in the mining sector, as well as the sentencing of Meng Han-the last labour activist on trial as part of the crackdown of December 2015-to twenty-one months in prison.

In the China Columns section, we present three essays that offer distinct perspectives on how the party-state manages and controls an increasingly unequal and fractured society. In The Neglected Side of the Coin: Legal Hegemony, Class Consciousness, and Labour Politics in China, Elaine Sio-ieng Hui reflects on the role of labour law in China as 'a vital vehicle through which the Chinese party-state has constructed capitalist hegemony with regard to state-capital-labour relations in the country'. In Migrant Labour and the Sustainability of China's Welfare System, Beatriz Carrillo Garcia outlines the trajectory of China's welfare system towards the inclusion of migrant labour and highlights the challenges posed by the economic slowdown. Finally, in What Does Wukan Have to Do With Democracy?, Luigi Tomba analyses the protests that recently took place in Wukan village, challenging some widely-held assumptions about the political nature of such landrelated social movements in the Chinese countryside.

In this issue, you will also find a forum on Interpreting Chinese Labour: Informalisation or Empowerment?, in which Anita Chan, Kaxton Siu, and Sarah Swider discuss how precarisation has impacted the Chinese workforce in key sectors of the economy. In the Work of Arts section, Ivan Franceschini reviews The Cow and the Goat Descend the Mountain, an album of ancient Chinese poems set to music by folk singer Zhou Yunpeng, reflecting on the role of poetry as a form of resistance. We conclude with the Academic Watch, which introduces the edited volume China at Work through a conversation with co-editor Liu Mingwei.

This journal is hosted by Chinoiresie. info. In the final pages of this issue, you can find highlights from the website. If you would like to contribute a piece of writing, please contact us; to receive this journal regularly by email, please subscribe to our mailing list. We welcome any feedback and we hope you will consider sharing this journal with your friends and colleagues.
The Editors,

Ivan Franceschini, Kevin Lin, and Nicholas Loubere 


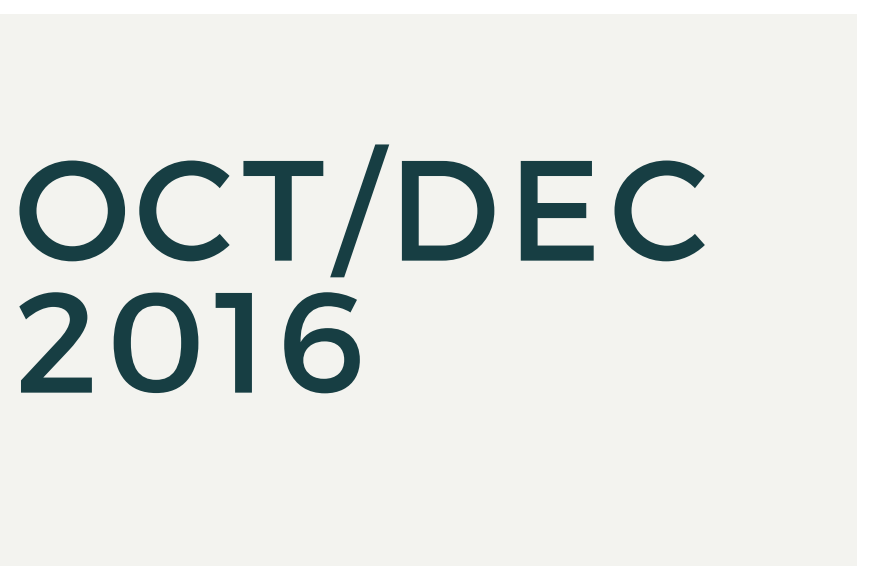

\section{Xi Stresses Party Leadership over State-Owned Enterprises}

On 11 October at a high-level national meeting Xi Jinping reaffirmed the centrality of Party leadership over China's state-owned enterprises (SOEs). According to the official Xinhua News Agency, Xi emphasised that under a stronger leadership from the Party-'the root and soul' of SOEs in his wordsSOEs should serve to implement the decisions of the Party, to promote national projects such as One Belt One Road, and to strengthen China's economic and social development and national power. $\mathrm{Xi}$ urged further reform of the management and supervision of SOEs in order to improve corporate profitability and competitiveness, and to increase the value of state assets. Xinhua reported that in 2016 central SOEs underwent merging and consolidation, and announced that next year the reforms will focus on cutting inefficiency and overcapacity of local SOEs. SOEs retain a dominant role in the Chinese economy: in the first half of 2016, the gross revenues of central and local SOEs (excluding financial companies) reached 21.39 trillion yuan, or more than sixty percent of the national gross domestic product. In the same speech, $\mathrm{Xi}$ pointed to state workers' rights to 'know, participate, express and supervise within the SOEs', and referred to the role of workers' congresses in the democratic management of the companies and in the resolution of labour disputes. This is likely in response to the state workers' protests early this year against the government's cutting of overcapacity in the steel and coal industries (see the article by Kevin Lin in MIC 1/2016).

(Sources: South China Morning Post, Xinhua 1, Xinhua 2)

\section{Tougher Rules for Ride-Hailing Businesses in China}

In October, some of China's largest citiesincluding Beijing, Shanghai, Guangzhou, Shenzhen, Chongqing, Tianjin, and Hangzhourolled out new regulations on internet-based ridehailing businesses. China has thus become the first country in the world to create a formal legal framework for the sector. The regulations limit the pool of drivers and vehicles, citing concerns about traffic and safety. However, the criteria are discriminatory toward migrants in that they require drivers to have a local household registration or at least to be long-term, tax-paying residents of the city with a temporary residence permit of no less than six months. In recent years, Internet-based ride-hailing businesses have flourished, attracting migrants to work as drivers: in Beijing, more than eighty percent of the ride-hailing drivers are migrants from outside the city. The ride-hailing businesses have also led to protests by taxi drivers who see their businesses squeezed by unlicensed taxi and ride-hailing cars. But, ride-hailing car drivers in China have held their own protests: for instance, in March, hundreds of Uber drivers in Hangzhou blocked roads and protested against entrapment by police. Uber China reportedly told its drivers not to clash with police.

(Sources: Bloomberg, Caixin 1, Caixin 2, Caixin 3, The Financial Times)

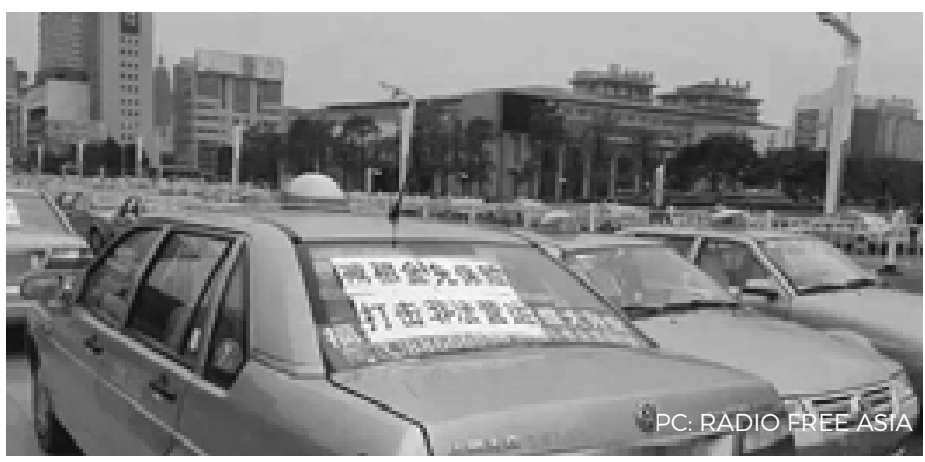




\section{Meng Han Sentenced}

On 3 November, Meng Han, the last of the labour activists detained in the crackdown of December 2015, was found guilty and sentenced to twentyone months in jail by the Panyu district court in Guangzhou. While detained, Meng Han was denied access to his lawyer, and his parents were repeatedly harassed in their apartment by unidentified men. After the announcement of the sentence, friends and fellow activists held a fundraising initiative to collect money to support Meng Han's living expenses while in jail, and about thirty unionists and labour rights groups in Hong Kong organised a protest outside the Hong Kong China Liason Office demanding his immediate release. Days before the trial, the International Labour Organisation's Committee on Freedom of Association released its interim report in response to a complaint launched by the International Trade Union Confederation. In it, the Chinese government was criticised for its treatment of labour activists, who 'appear to have been arrested, detained and charged for being involved in a labour dispute and considers that the detentions of persons connected with their activities in defense of the interest of workers constitutes a serious interference with civil liberties in general and with trade union rights in particular.' Labour NGOs all over the country are under increasing pressure. In Beijing, the Migrant Workers' Home, a historic labour NGO that focuses on cultural activities for migrants, is facing eviction after more than ten years. The enforcement of China's Foreign NGO Management Law in January 2017 will make it increasingly hard for NGOs to gain access to vital financial support from abroad (see the compendium of the Law in MIC 2/2016).

(Sources: China Labour Bulletin, Jiliuwang, South China Morning Post, The Initium)

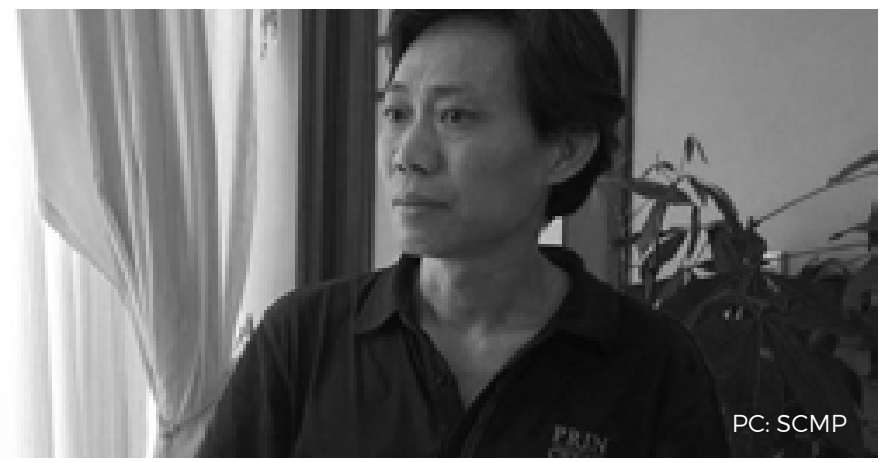

\section{Mine Blasts Kill Dozens}

On 27 September, a gas explosion in a coal mine in Ningxia took the lives of twenty miners. Similar explosions killed thirty-three miners in the municipality of Chongqing on 31 October, twenty-one miners in Heilongjiang province on 29 November, and thirty-two miners in Inner Mongolia on 3 December. More recently, on 5 December a gas explosion resulted in the deaths of eleven miners in Hubei province. Being the world's top producer and consumer of coal, China has a tragic history of mine explosions. In recent years, authorities have been swift to crack down on unsafe mining operations. Commenting on the blast in Chongqing municipality, the State Administration of Coal Mine Safety said that despite the fact that the mine operation was fully licensed, it was still unsafe and illegal. In particular, the mine was too deep and the underground facilities did not have adequate ventilation. The State Administration has ordered all Chongqing mines to halt operations and conduct immediate safety inspections. China's national safety regulator has also warned coal mines not to operate beyond their daily capacities, as rising prices tempt mine owners to increase production. In several cases, safety officials have been fired and mine operators arrested.

(Sources: Sixth Tone, South Cahina Morning Post, Xinhua)

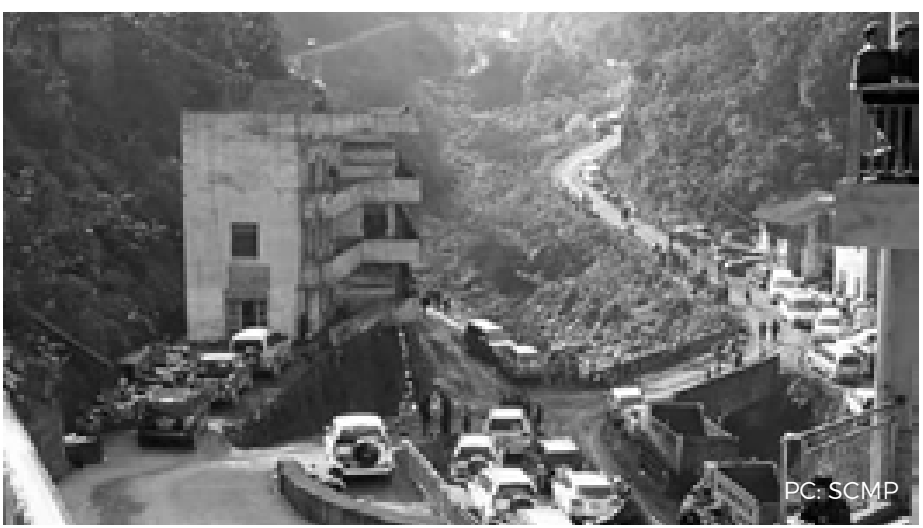




\section{Parents of Left-Behind Children Face Prosecution}

According to an official survey on the migrant population in China in 2016 released in mid-October by the National Health and Family Planning Commission, around sixty-one million childrenmore than a third of whom are younger than seventeen-currently live in the Chinese countryside without the daily care of their parents, who have migrated to other areas for work. These so-called 'left behind children' (liushou ertong) are a serious social problem in China. Earlier this year, Zhang Dandan a professor at Peking University, released the result of a survey of one thousand two hundred criminals in prison: about seventeen percent of them had been 'left behind children'. Tragedies are common. Earlier this year, three children, who had been left in the care of their grandmother by their migrant parents, drowned in a pond near their home village outside of Nanchang, Jiangxi province. There have also been some instances of suicide. In January 2014, a nine-year-old child hanged himself in the house of his grandparents in Huayang, Anhui province, after learning from his grandmother that his mother, a migrant worker, was not going to come home for the holidays. In June 2015, in a village in Bijie, Guizhou province, a thirteen-year-old boy and his three younger sisters killed themselves after having been left alone for months by their migrant parents. To prevent such tragedies, in February 2016, the State Council ordered local governments to establish a database of these children and issued guidelines to improve the physical and psychological health of such children. In November 2016, the Ministry of Civil Affairs, along with the police, the judicial departments, and the Ministry of Education announced a clampdown on parents who leave behind their children. Parents who fail to provide their children with proper parental care for six months or longer now can lose their custodial rights at the request of their relatives, village officials, or civil-affairs authorities.

(Sources: Caixin, CCTV, State Council, Zhongguo Qingnianbao, National Health and Family Planning Commission, South China Morning Post, The Paper)

\section{Strikes at Multinational Companies in China}

The last quarter of 2016 witnessed a series of strikes among the employees of several multinational companies in China over ownership changes. First, on 8 November, dozens of employees went on strike at a bottling plant owned by Danone in Guangzhou that had just been sold to a local company after learning that the French multinational was refusing to offer severance payment according to the workers' years of employment on the pretext of the unchanged corporate name. After two weeks of strike, the company agreed to meet with the workers, but on that occasion the riot police entered the factory grounds and attacked the workers, with the result that several were injured. On 10 November, workers at a smartphone camera parts factory in Guangzhou owned by Sony went on strike for two weeks after the company announced the sale of the plant to a local company. They feared that working conditions and pay would suffer and jobs would be lost under the new ownership. To end the protest, the Japanese company paid off the workers with one thousand yuan each and fired dozens of strike leaders. Finally, on 23 November, protests erupted among workers in three plants owned by Coca-Cola in Chongqing, Chengdu, and Jilin province, when it was announced that the American company was going to sell all its bottling plants in China to a Chinese state-owned food giant. The workers feared that after the sale they would lose their jobs or get lower wages, so they launched these coordinated strikes to demand the disclosure of the details of the agreement and economic compensation.

(Sources: Caixin, China Labour Bulletin, Nikkei, Red Balloon Solidarity, The Guardian)

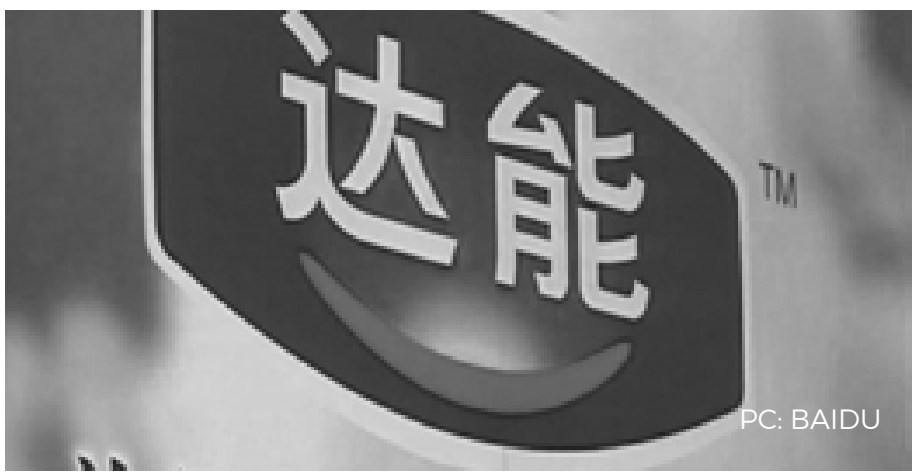



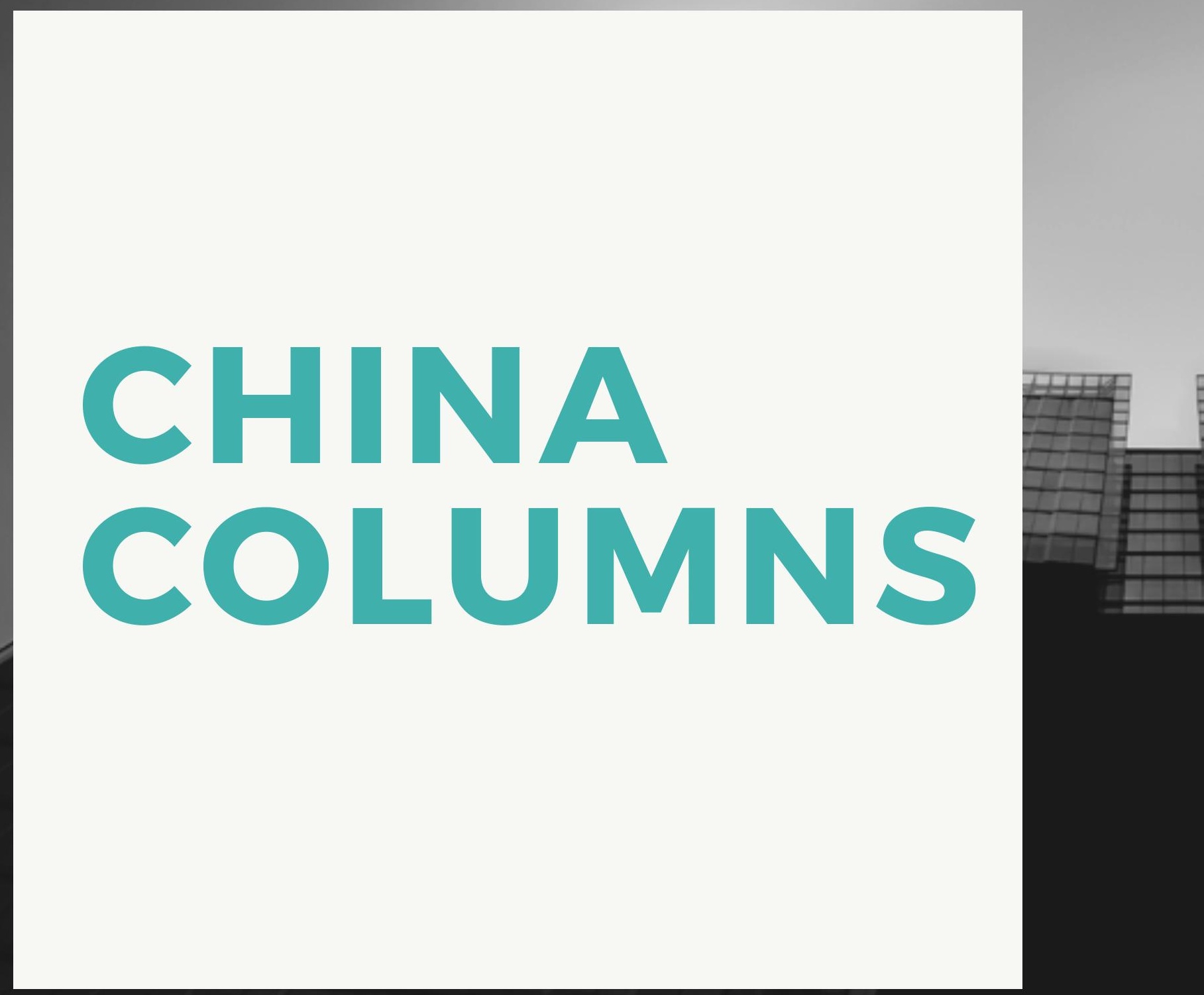

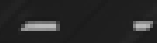

$=-$

- $=-$

$$
\text { - }- \text { - }
$$

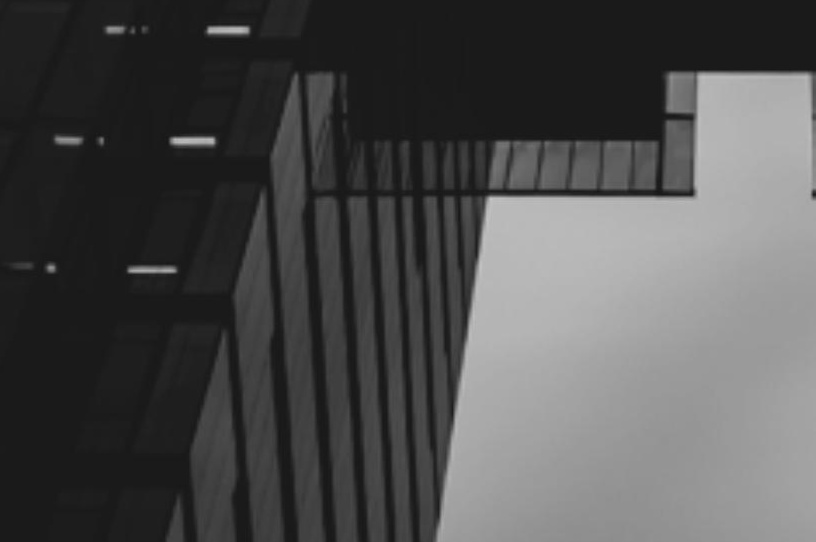




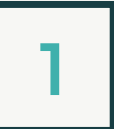

\section{The Neglected Side of the Coin:}

Legal Hegemony, Class Consciousness,

and Labour Politics in China

Elaine Sio-ieng Hui

\section{2}

Migrant Labour and the Sustainability of China's Welfare System

Beatriz Carrillo

$$
3
$$

What Does Wukan Have to Do With Democracy?

Luigi Tomba

$\cos$

$\infty \quad+=$

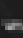

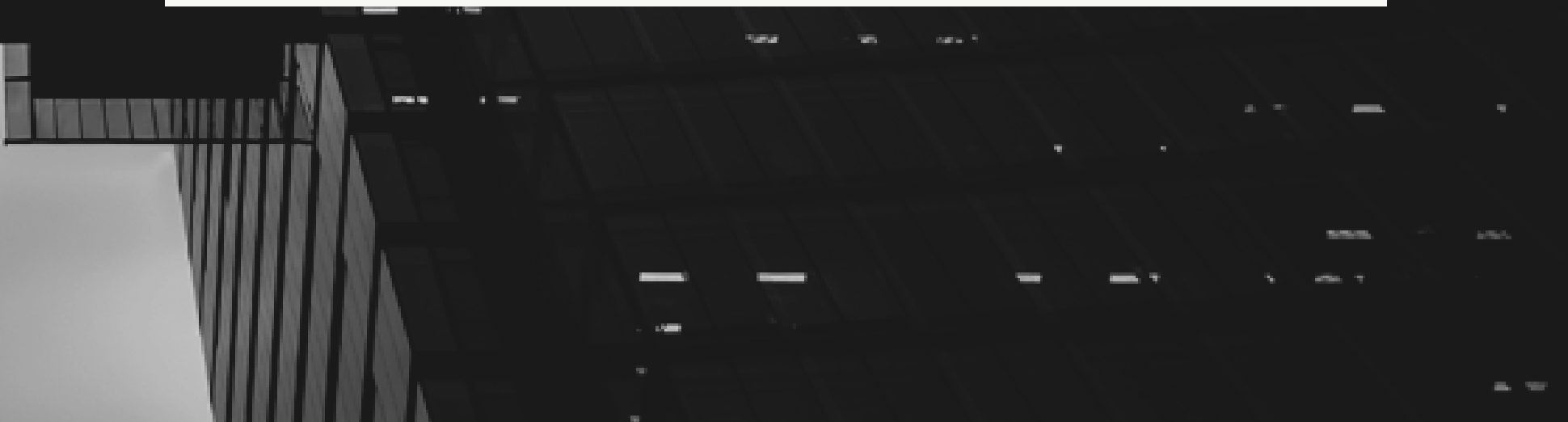




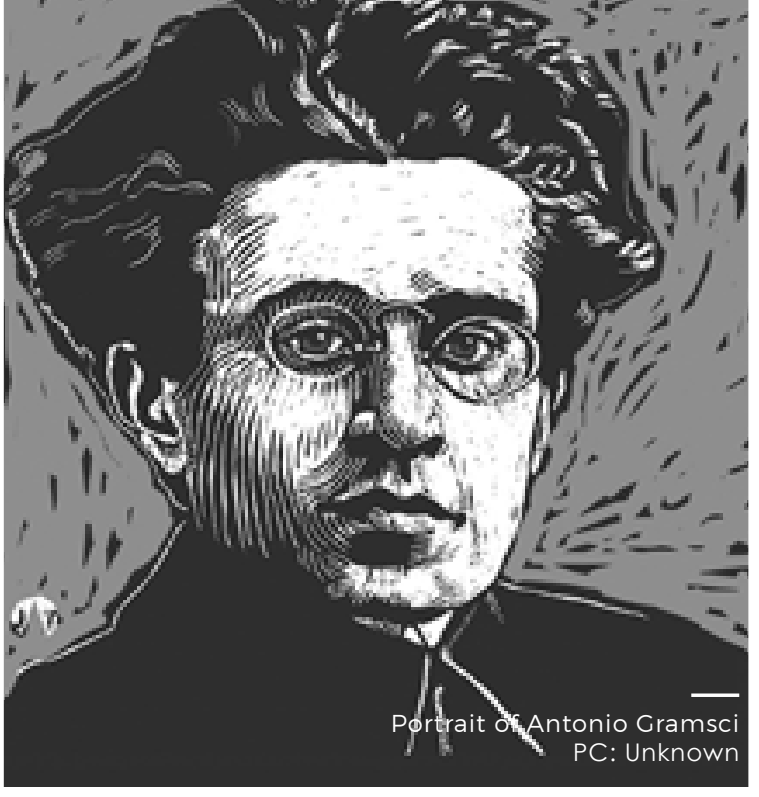

The Neglected Side of the Coin:

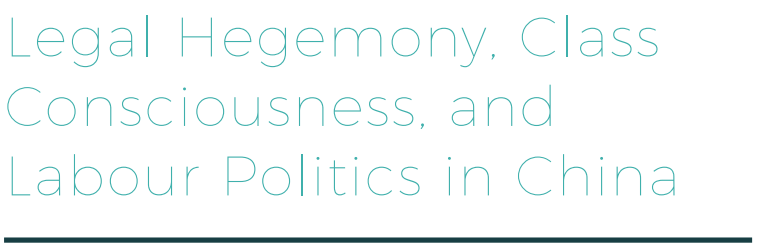

\section{Elaine Sio-ieng Hui}

Since China's opening up, the Chinese party-state has put great effort into reforming the labour law system. Taken at face value, the new laws and regulations adopted in these decades may be easily be seen as a sign of the commitment of the party-state to advance labour rights. This article contradicts this view through an examination of how the labour law system in China has been utilised to build up hegemony and dampen workers' class consciousness.

This article is based on two of the author's publications: 'The Labour Law System, Capitalist Hegemony and Class Politics in China', The China Quarterly (226): 431-455; and Hegemonic Transformation: The State, Laws and Labour Relations in Post-Socialist China, Palgrave Macmillan, New York (forthcoming).
Since China's opening up in 1978, the Chinese party-state has put great effort into reforming the labour law system. During the 1990s, the 1992 Trade Union Law, 1994 Labour Law, and the 1995 Arbitration Law were enacted. In 2001 and 2004, the revised Trade Union Law and Provisions on Minimum Wage were promulgated respectively. In 2007, the Labour Contract Law was passed. All these events may be easily taken at face value as a sign of the commitment of the party-state to advance labour rights.

This article, however, argues that the labour law system is a vital vehicle through which the Chinese party-state has constructed capitalist hegemony with regard to state-capital-labour relations in the country. While Marx and Engels, as well as Lenin, mostly focussed on the oppressive nature of the state, in Prison Notebooks Gramsci advanced the idea that the power of the ruling class is organised by the state in both political society and civil society through 'coercion' plus 'hegemony'. He contended that the coercive machinery of the state helps sustain the domination of the capitalist class, but at the same time it has to acquire the active consent of the working class by establishing what Joseph Femia termed 'its own moral, political and cultural values as conventional norms of practical behaviour' in order to sustain its class rule. The ideological ascendency of the capitalist class over the subaltern classes is what Gramsci called 'hegemony'.

For years, Chinese migrant workers have carried out contentious actions to strive for defaulted wages, compensation for workplace injury, overtime payment, and so forth. Recently, democratic enterprise trade union elections, decent wages above the minimum wage rate, compensation related to factories' closure or relocation, and payments of social insurance have also been key demands of migrant workers. Some studies point out that migrant workers have manifested a growing level of class consciousness over 
time. Workers' class consciousness and capitalist hegemony are two sides of the same coin. Hegemony is the endeavour of the ruling class to constitute workers' worldviews and values in such ways that the latter may criticise, but not challenge fundamentally, the legitimacy of the capitalist economy and the party-state, and that they may resist, but not take rebellious actions to transform the sociopolitical and economic systems. In other words, through establishing capitalist hegemony, the ruling class aims to forestall the emergence of workers' class consciousness, which is a cardinal factor in inducing system-changing initiatives. Focussing on the often-neglected side of the coin, this article examines how the labour law system in China has been utilised to build up hegemony and dampen workers' class consciousness.

\section{The Double Hegemony Buttressing Market and Party-State}

The labour law system has been given a greater role in the mediation of industrial relations in post-reform China. The concept of 'yifa zhiguo' (rule of law) was added to the Chinese constitution in 1999 and the notion of 'yifa weiquan' (defending rights according to the law) has been widely promoted by the partystate (see also the Forum in MIC 2/2016). The labour law system has produced a double hegemony, which seeks to deflect radical worker opposition against both the market economy and the party-state. Concerning capital-labour relations, despite complaining about poor income, many workers still approve of the meagre wages offered by their employers. As one female worker whom I interviewed back in 2013 remarked: 'I go to work according to the schedule; it is fair and just, so long as my employer does not underpay me.' Another male worker I interviewed noted that 'labour laws must have been passed for good reason. They were made by professionals; they, thus, must have taken into consideration national and social needs.' Many workers have taken labour laws as a yardstick for measuring employer behaviour-if employers do not violate the Labour Law, then paying workers low wages is not unjust. This 'normalising mechanism' embedded in the labour law system does not simply legitimise low wages, but also covertly endorses market principles such as waged labour, private property rights, surplus value extraction, commodification of labour, and so forth.

Another mechanism-which I define as a 'countervailing mechanism'-is incorporated into the labour law system to strengthen capitalist dominance. Despite its pro-capital essence, the labour law system provides aggrieved workers with a platform for resolving labour disputes, such as mediation, arbitration, and litigation. Being unaware of the many limitations of this system, because of the countervailing mechanism, many workers believe that the market economy is not structurally exploitative, and that their hardships are a result of erratic misdeeds from idiosyncratic employers. In one of my interviews, a migrant worker commented: 'Some factories are really bad... But when my employer is problematic, I can simply complain to the labour bureau or sue the boss. There was no law when we first worked in the cities; now things have improved.' For some workers, the juridical sphere is autonomous from the capitalist economy, and labour laws are a useful tool for remedying misbehaviour occurring in the economic realm.

Concerning state-labour relations, the abundance of labour laws in China, which on paper are very comprehensive and seemingly try to constrain and regulate employers, has convinced some workers that the party-state protects workers. They, thus, do not attribute worker 
misfortunes to the state's pro-capital bias. As a worker I interviewed noted: 'In the past, there were no regulations on wages, and we just earned a little. But now, enterprises must follow the laws and pay us the minimum wage. Our situation is much better now...' This 'concealing mechanism' embedded in the labour law system induces some workers to believe that the Chinese political regime is 'autonomous' from the market economy and is willing to curb economic misdeeds. Hence, they do not fundamentally challenge the party-state's legitimacy.

The concealing mechanism usually goes hand in hand with another mechanismthe 'transmuting mechanism'-to protect the Chinese Party-state from workers' radical challenges. Due to the decentralised politics of China, the central government delegates the task of capital accumulation to local governments, while it focuses its attention on maintaining political legitimacy and social harmony. Some workers, therefore, perceive government corruption and its pro-business bias as being caused by local governments or officials. In the words of a worker I interviewed: 'I think the central government doesn't have any problems; it has legislated many labour laws to protect workers. The problem lies with the local governments who protect businesses too much.' In brief, the transmuting mechanism shifts the target of workers' contempt from systemic state-capital collusion to local governments.

\section{An Uneven Influence}

Through the aforementioned four mechanisms, the labour law system has been able to impose double hegemony on some workers. However, the double hegemony has influenced Chinese migrant workers in an uneven manner. Some workers have granted active consent to the ruling class through the mediation of the labour law system, while some others have rendered passive consent. Some, however, have given no consent at all. Those workers who have rendered active consent to the capitalist leadership approve of the official legal discourses and labour law practices (see also the article by Ivan Franceschini in MIC 2/2016). Most of them perceive of economic reforms and economic growth in a positive light. They endorse the state's development strategy of 'letting some people get rich first', which is akin to the liberal 'trickle down economics' theory, believing that economic progress fuelled by the state's pro-business policies will eventually benefit other members of the society. Many of them believe that employers would have been above reproach had they paid workers wages according to the labour laws. The market economy and the wealthy class are thought to have created jobs for workers and prosperity for the country, rather than exploiting labour.

Workers who have rendered passive consent to capitalist leadership have neither completely assented to it, nor fundamentally challenged it. Some workers do not place full trust in the labour law system because of the gap between their work experiences and the unfulfilled promises of the official legal rhetoric. However, the labour law system is still able to elicit passive consent from them because, as Joseph Femia put it, their 'spontaneous discontent is contained by the preexisting categories of the dominant ideology'. This means that, even though they disapprove of the juridico-political and economic system, their criticism is constrained by the ideational framework produced by the ruling bloc. Although these workers discredit the labour law system, their criticism usually targets implementational issues rather than asymmetrical power relations embedded within the system. Many of them maintain that the central government has good intentions to protect workers with labour 
laws; they attribute the failing labour law system to the fault of local governments or officials.

Some workers have given no consent to the ruling class at all. These workers have formulated radical challenges to both the market economy and the party-state; and they refuse to follow the ruling bloc's leadership. They are relatively immune to the normalising mechanism of legal hegemony. They do not see legal minimum wages as fair or just; instead they measure their wages against how much their employers earn. In addition, they are not influenced much by the countervailing mechanism. Some of them understand that the legal and the economic are not independent from each other; that the law-making process and legal content are biased towards employers; and that workers and capitalists are on unequal footing within the legal realm. Moreover, the concealing mechanism and the transmuting mechanism have little effect on them. They see through the intricate relations between government and businesses, and do not construe the party-state as wholly autonomous from the capitalist class. They do not simply blame the local governments or officials, but censure the central government or the party-state en bloc.

\section{Precarious Hegemony}

The differing degrees in which the impact of this legal hegemony on workers expose its fragility and precariousness, which are the results of a number of factors. At the economic level, unbalanced economic development and growing social inequality have laid the material foundation for worker contestation to capitalist leadership. At the associational level, the Party-led trade unions are unable to secure short-term material concessions for workers and, hence, worker allegiance to the ruling bloc. At the legal level, the party-state has failed to consistently uphold the legal ideals it has reproduced; the discrepancies between legal ideals and legal reality have produced disenchantment. In July 2015, more than two hundred rights-lawyers and legal assistants were detained by the government without following proper legal procedures. In December of the same year, seven labour NGO activists were arrested-five of them were formally charged at a later date for 'gathering a crowd to disrupt public order' and 'embezzlement'-and they were denied many legal rights, such as the rights to communication with lawyers and families. Some of the detained activists were made to confess their alleged crimes on television. These incidents have aroused tremendous concern at both the international and national level. Still, it is important to highlight the fact that the greater the discrepancies between the government's rhetoric and the legal reality is, the easier it is for workers to become distrustful of the juridicopolitical system and to overcome the deception of the legally-mediated double hegemony.

\section{Elaine Sio-ieng Hui}

Elaine Sio-ieng Hui is an Assistant Professor in the School of Labor and Employment Relations at the Pennsylvania State University. Her research interests include critical state theories, legal theories, class consciousness, civil society, social welfare, and labour relations in China. 

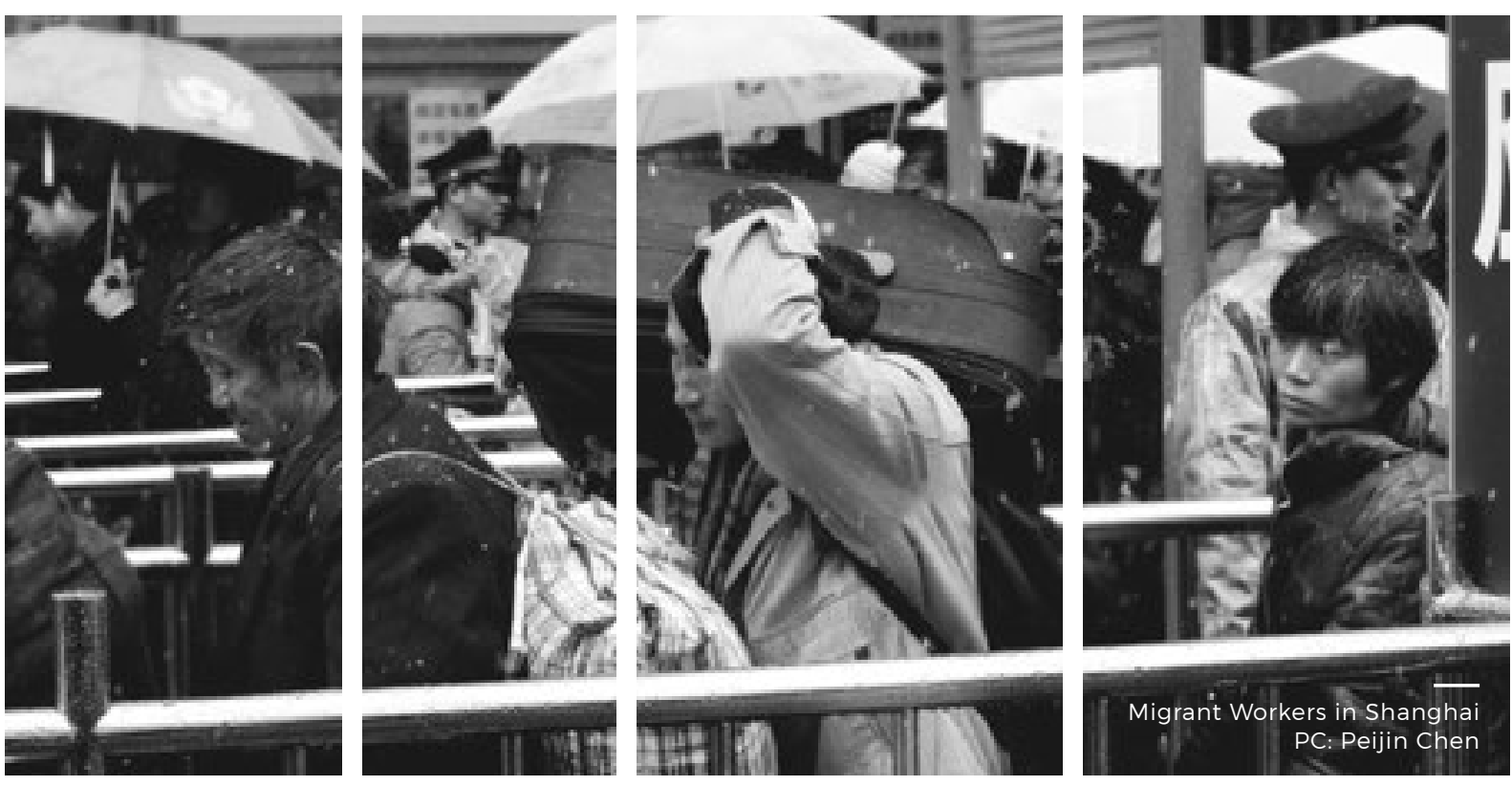

Social welfare in China has emerged in recent years as a major cause of migrant workers' discontent and collective action. Reforms of the social welfare system in China since 2002 have expanded coverage and protection of vulnerable populations, but structural problems remain for migrant workers to access and receive the full benefits of the social safety net. How has the social welfare system evolved, and what are the challenges facing migrant workers? How can the system be made more sustainable?

Social welfare-understood broadly as encompassing public services, social insurance, and social relief-has long been primarily the privilege of the urban population. From the inception of the People's Republic in 1949, urban citizenship-defined by people's household registration (hukou) status-provided urban residents with access to employment, housing, education, and social insurance not available to rural hukou holders. China's rural-urban divide has, thus, in many ways been defined by this gap in welfare provision.

The traditional 'iron rice bowl' (tiefanwan) system, based on work units (danwei), provided urban workers with 'cradle to grave' employment, services, and security, but-perhaps more importantly-it also gave these workers an identity and a 
sense of entitlement. This perception of having a right to state provisions was not developed among China's vast rural population, since they received very limited or no state funding for welfare provision. With the start of the reform era, workers' identity and sense of entitlement had implications for the demands for provision they made on the state, but also with regard to whose benefits the state decides to maintain or cut.

By the late 1990s, for example, China's previously privileged old working class was laid-off in the millions from stateowned enterprises-the majority left without welfare benefits (see also the article by Kevin Lin in MIC 1/2016). In the meantime, up until 2015, civil servants had largely retained their superior social insurance benefits, funded in their entirety by the state. In contrast, having had limited or no experience of state support, most rural-to-urban migrant workers had not had a sense of entitlement to urban goods and welfare, not least because in most cases their rural hukou continues to deny them membership in the cities. And yet, among the second generation of rural migrants-born after 1980 and with weaker links to the countryside-that has begun to change. These workers are demanding better pay and working conditions. Their reaction to, and demand for, social insurance entitlements, however, has been less enthusiastic. This is in part due to the shortcomings and limitations of the social insurance system itself.

\section{A Fragmented System}

China's social insurance system is highly fragmented. While hukou differentiation may be the more obvious element of that fragmentation, other factors related to the way in which these insurance programmes are funded, managed, and implemented have perhaps had more serious implications for their provision. Like economic policy, social policy implemen- tation in China is highly decentralised, and thus dependent upon local state capacity, particularly financial well-being. The more developed and wealthy provinces of the east coast have thus been better able to meet policy mandates from the central government around the delivery of public goods, social insurance, and welfare benefits, and have often even surpassed the level of benefits established by the centre. In contrast, having no revenue to match their welfare responsibilities, many local governments in the central and western parts of China offer, at best, very patchy provision. A longitudinal study on the social determinants of health, for example, found region (where a person lives) to have the strongest effect on an individual's health status (gender and age being the other two most important determinants).

This decentralisation, including the fact that funds for social insurance are pooled locally, has meant that funds accrued in individual worker accounts have not been transferable between jurisdictions. This lack of transferability is one of the biggest disincentives for migrant workers to enrol into the social security system, even when special insurance programmes for migrant workers have been created, as has been the case in Shenzhen and in other cities. Furthermore, these social insurance programmes for migrants usually provide lower benefits than those covering formal urban employees, and there have been various well-publicised cases of employers not paying their contributions into those schemes. Rural migrant workers are thus-understandably-reluctant to join a system that will result in less cash-in-hand and limited benefits only available in situ.

\section{Attempts at Harmonisation}

In order to allow for the transferability of funds accumulated in individual 
workers' social insurance accounts, since 2008 the central government has promoted the 'harmonisation' of rural and urban social insurance programmes, with the aim of creating a unified national social security system. In practice, however, this rural-urban harmonisation has thus far tended to result in local welfare protectionism, whereby the more prosperous provinces are unwilling to share their larger fund pools with workers from outside their jurisdiction. Chongqing's municipal government, for example, has successfully unified its rural and urban social insurance programmes for those with a local hukou, but those from outside the municipality remain left out. Given that rural migrant workers are now more likely to be working outside their home province, in the short to medium term the rural-urban harmonisation process is likely to only benefit a minority of migrant workers.

The policy and rhetoric coming from the centre, however, has continued to promote the inclusion of rural migrant workers into the urban social security system, as evidenced by the latest iteration of the Social Insurance Law, passed in 2011, which made the enrolment of migrant workers into the urban social insurance programmes compulsory. Local governments have nonetheless not been too keen to police the implementation of this law, for fear of upsetting local businesses and industry. Employers in China have indeed faced some of the highest employee insurance contribution rates in the world, with rates of up to forty percent of employees' wages. In some provinces and municipalities, contributions into the old age social insurance alone have stood at more than twenty percent of the payroll. This serves to explain the prevalence of casual and informal employment without benefits, in which the majority of rural migrant workers are involved.

\section{Economic Slowdown as the Latest Challenge}

China's economic slowdown is likely to result in yet fewer employers willing to enrol migrant workers into the social insurance schemes mandated by law. In response to this, earlier this year the central government reduced employer contribution rates for pension and unemployment insurance, and for the housing provident fund. Nevertheless, the central government is likely to continue to put pressure on sub-national governments to enrol rural migrant workers into the social insurance system, because it now
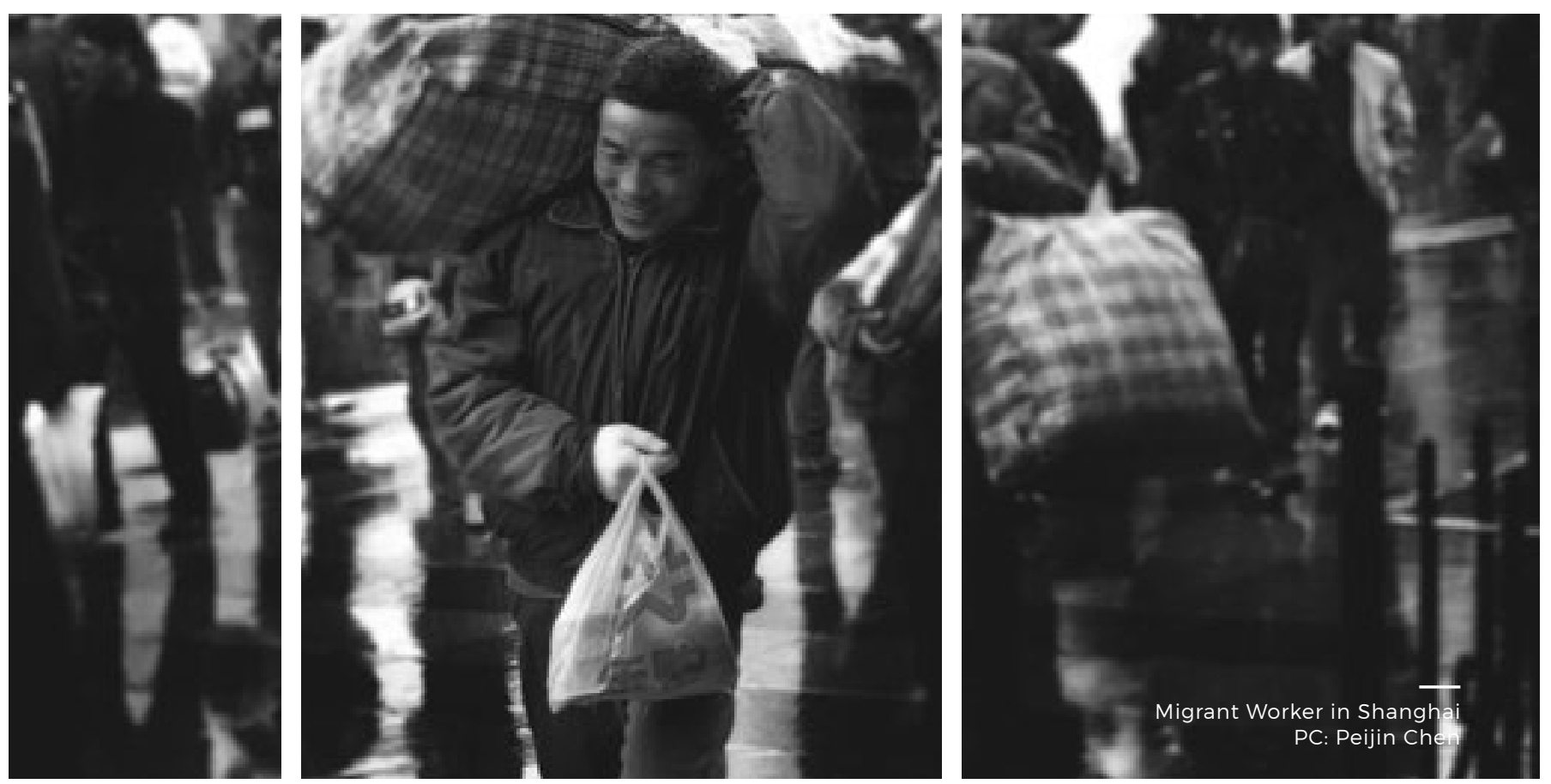
realises that the financial sustainability of the system will depend on bringing in more contributions from the working-age population. As a cohort, rural migrant workers are, on average, younger than their urban counterparts; these younger worker's social insurance contributions are hence necessary to sustain the needs of China's ageing population and the sustainability of the pension system.

The first generation of rural migrant workers is also ageing and has begun to demand access to medical insurance and to a pension. More generally, the needs and demands of rural migrant workers for public services and social security are also changing. For example, the number of migrants travelling with their families has increased substantially over the last couple of decades. These migrant families have different housing needs, their children need access to local child care facilities and schools, play areas, medical services, and so on.

While workers' movements, strikes, and demonstrations have, in several instances, won rural migrantst workers better working conditions and pay, the expansion of social insurance and welfare programmes has largely been a top-down affair. More recent demands by migrant workers over social insurance payments, such as in the case of the 2014 strike at Yue Yuen-a shoe manufacturer and Adidas and Nike supplier-have also served to influence the government's decision to expand rural migrant workers' social insurance rights.

Again, the concern over a reduced worker/pensioner ratio and the burden that this will place on China's social security system is likely to maintain the commitment of the centre to expand coverage to include rural migrant workers. Some provincial governments, as stated earlier, are likely to continue to delay that process. Apart from financial considerations, Mark Frazier has also argued that it would be unwise for the Chinese government to retreat from the politics of inclusion and access to social policies introduced as part of Hu Jintao's campaign to build a 'Harmonious Society' (hexie shehui) and continued under Xi Jinping's 'Chinese Dream' (zhongguo meng). Rather, what economic slowdown might bring about is a reduction in the level of benefits that employees receive, as signalled by the recent cutback to mandated employer contributions into social insurance programmes. Universal coverage may well soon be achieved, but at a very basic level of coverage. Whether this will constitute a real safety net for all remains to be seen.

\section{Beatriz Carrillo}

Beatriz Carrillo is an Associate Professor at Xi'an Jiaotong Liverpool University in Suzhou, China. Her research focuses on social exclusion and inclusion of rural migrant workers, welfare policy, social determinants of health, and philanthropy in contemporary China. 


\section{What Does Wukan Have to Do With Democracy?}

\section{Luigi Tomba}

In September 2011, the village of Wukan, Guangdong Province, made international headlines for its violent protests against the illegal sale of land by their corrupt village elite. Villagers were successful in both toppling the existing village leadership and electing, in their stead, the moral leaders of the revolt as their new village committee. A few months ago, the original leader of the protests was arrested on unclear corruption charges, an event that led to violent clashes between villagers and police. Is Wukan's sad story an example of a conscious democratic challenge to the existing system?
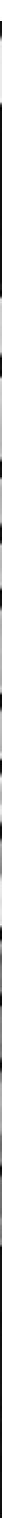
In September 2011, the village of $\mathrm{Wu}$ kan in Eastern Guangdong province became the centre of a media storm and made international headlines for its violent protests against the illegal sale of land by their established, and corrupt, village elite. Village leaders had taken it upon themselves to sell large chunks of village land without consulting the villagers, formally the collective owners of the land-use rights. Villagers in Wukan were successful in both toppling the existing village leadership and electing, in their stead, the moral leaders of the revolt as their new village committee. What was more important, in the tightly controlled Chinese system of village elections, was that villagers were allowed to cast a secret ballot.

Yet, despite international media calling Wukan the ultimate example of a democratic trend in rural China, the situation of the villagers changed little. The government claimed that part of the land-stealing controversy was resolved 'according to the law', which took some of the wind out of the sails of the collective protests. Ultimately, however, the land-use rights were not returned to their owners. The new leadership rapidly split and members of the newly elected village committee were then investigated for petty acts of corruption and were themselves forced to write 'confessions'. The original leader of the protests, Lin $\mathrm{Zu}$ luan, was re-elected in 2015 with ninety percent of the votes, only to be arrested on unclear corruption charges in mid2016. As it so often happens in these corruption cases, facts and circumstances are hard to ascertain. An Al Jazeera series of reports exposed the banality of village in-fighting between 2012 and 2015, along with the progressive re-assertion of state control over the conflict-ridden village. The arrest of Lin, seen by many as a moral beacon in this complex story, led to new violent clashes with the police, and to the almost inevitable analysis of the end of Wukan's 'democratic experiment'.
Is Wukan's sad story an example of a conscious democratic challenge to the existing system, as it has often been argued? Is every conflict in China that attracts the attention of the media a new step towards an inevitable democratic future? The battles in the streets, with national flag-bearing villagers throwing stones at riot police are generated much less by a desire to change the political system than they are by the exclusion of countless villagers from the spoils of economic growth and urbanisation. Villagers have seen the value of their land grow and the profits of urbanisation being appropriated by greedy local elites in the name of national development. Villagers' slogans are invariably about the redressing of a wrong, not a call for a rather distant idea of democracy. In a competition with the predatory urban governments, the cards are stacked against the village collectives, often leaving little alternative to violence. And these conflicts are everywhere, potentially much more significant for prosperity, stability, and justice in China than for its democratic future. Arguing that the story of Wukan is about China's transition into a liberal democracy would be forgetting the structural conditions that have led to this local conflict in the first place.

\section{Urbanisation and Land Ownership}

To explain some of these conditions, let's take a step back. One of the pillars of China's authoritarian system, and the main remnant of its socialist planned past, is the public ownership of land. In the cities, this takes the form of 'state ownership' while in the countryside the collectives (the villages) can claim the ownership of use rights over agricultural land. Villages are not formally considered to be a level of 'government', but are instead a level of 'self-administration'-a subtle but important distinction that 
contributes to explaining why villages committees are the only part of the governance structure where leaders can be elected, not appointed.

In this context, urbanisation inevitably necessitates the 'conversion' of collectively owned land into state-owned land. Urban administrations reap significant advantages from conversion, as the price of expropriation or acquisition of rural land is invariably a small fraction of the price that they can obtain when they lease the land on the market. The competition is very intense and a matter of survival for both villagers and urban governments. Various estimates suggest that, on average, villagers end up being significantly short-changed. According to a report by Jiang Ming at Peking University, the market price of expropriated land is, on average, more than fourteen times higher than the cost of compensation. There are, of course, substantial variations, and some strategically located peri-urban villages have successfully negotiated handsome compensation packages through unified and collective bargaining, especially when, because of rapid urbanisation, some of these 'urban villages' have ended up owning land in central areas of Guangzhou or Shenzhen. Yet, in general, these remain the exception rather than the rule, and local governments use violence and even local thugs to evict village residents.

City governments can be only partly blamed for having such an aggressive stance. This is because growth in their territory, their capacity to provide services to an increasing population, and their implementation of higher-level government policies remain highly dependent on land. Because of the centralised taxation system, land fees are among the few components of an urban government's revenue that stay local. This has turned cities into aggressive agents of expropriation as, according to the law, rural land can only be turned into 'construction land' once it has been converted to state-owned land and their inhabitants relocated or given an urban household registration (hukou). Despite central attempts to limit expropriation in the name of the preservation of the already limited amount of arable land in the country, the dependence of local governments on land sales has continued to grow over the last decade. On average, more than one quarter of urban governments' budget depends on land fees, and in some cities it is as high as forty or fifty percent. In 2012 alone, income from land fees grew nationwide by more the forty-six percent.

\section{The Plight of Chinese Villagers}

Villagers, for their part, have experienced expropriation since the 1980s. In the early period, it was easier for them to justify the state's intervention with the needs of economic development. Yet, after three decades of successive expropriations, the cases of neighbouring villages and the declining attraction of urban welfare (an urban registration was often offered in exchange for land-use rights) have made it more difficult and expensive to convince farmers to give up their land. With a much greater flow of information, they now know how much governments speculate on the land that is taken away from them, and they are no longer ready to sacrifice their interests in the name of national development.

Many 'rural' villages on the outskirts of large cities are also no longer relying on agriculture. Despite the legal limitations, they have often built significant collective industrial economies on their land and are now living from rent paid by factories, as well as the income generated by a growing army of migrant workers who need accommodation, food, and services. They no longer see their land as a munificent concession of the socialist state but as a long-held entitlement, and have created complex local institutions to control 
their collective economies. Shareholding cooperatives have been set up, for example, that spread from Guangdong to many other parts of the country, turning villagers into shareholders of their village corporation. Shares (that cannot be sold outside of the collective) have now replaced land, and traditional village elites have consolidated their capacity to decide on important aspects of the village economy with limited consultation with the villagers.

These are concerns that Wukan's villagers are familiar with and clearly not only theirs. About two-thirds of the estimated 187,000 collective conflicts a year across the country have something to do with land. Last year, land also replaced corruption as the main area of dissatisfaction in the government's work among Chinese citizens, probably suggesting that, while the centrally engineered anti-corruption campaign is generating positive vibes, the aggressive stance of local urban governments (and the growing prices of real estate) is increasingly becoming a focal point in China's public opinion.

\section{Wukan as Symptom of a Rural Malaise}

When we think of Wukan in these terms, the democratic content of the violent resistance to the government's attempt to re-establish control over the village is hardly an indication of a growing democratic awareness, or a strong opposition to the existing institutions. Rather, the grievances stemming from the longterm infringement of local interests and the perception of being cheated by the local government contribute decisively to strengthening the resolve of these villagers. Yet, they hardly see the change of the current institutional arrangements as a solution to their grief. Much of the contestation has to do with the corruption of some officials. The election of their own leaders was supposed to return the land that was originally sold without their consent. The autonomy and special rules in the Wukan elections are part of the concessions resulting from the bargaining process in which local governments invariably engage when conflicts arise. By keeping that autonomy localthe result of specific negotiations, not a rule change-they very efficiently deny the possibility that a more democratic arrangement can emerge, that the legitimacy of higher-level leadership is affected, and that, eventually, the Wukan experience is systematically replicated.

This incident, and the massive contestation in the village between 2012 and 2016 is a very visible sign of China's rural malaise. Urbanising China is a massive attempt to nationalise its territory, to absorb collective economies that have in the last two decades been at the centre of China's industrialisation. It is driven by the structural needs of urban governments and observed with continuous apprehension by central authorities, always ready to tailor their intervention to the different realities of urbanisation in the country, to quell conflicts when they risk spilling beyond their local dimension. To look at Wukan as an experiment in local democracy would be too generous an evaluation for the current authoritarian government.

\section{Luigi Tomba}

Luigi Tomba is Associate Director of the Australian Centre on China in the World, The Australian National University. While his early research focused on China's labour reform, Luigi's best-known work is on urbanisation, the social engineering of a Chinese urban middle class, housing and land reform. His current research interests are informed by China's urban question, the ideological implications of China's project to urbanise the country, and its social, political, and territorial consequences. 


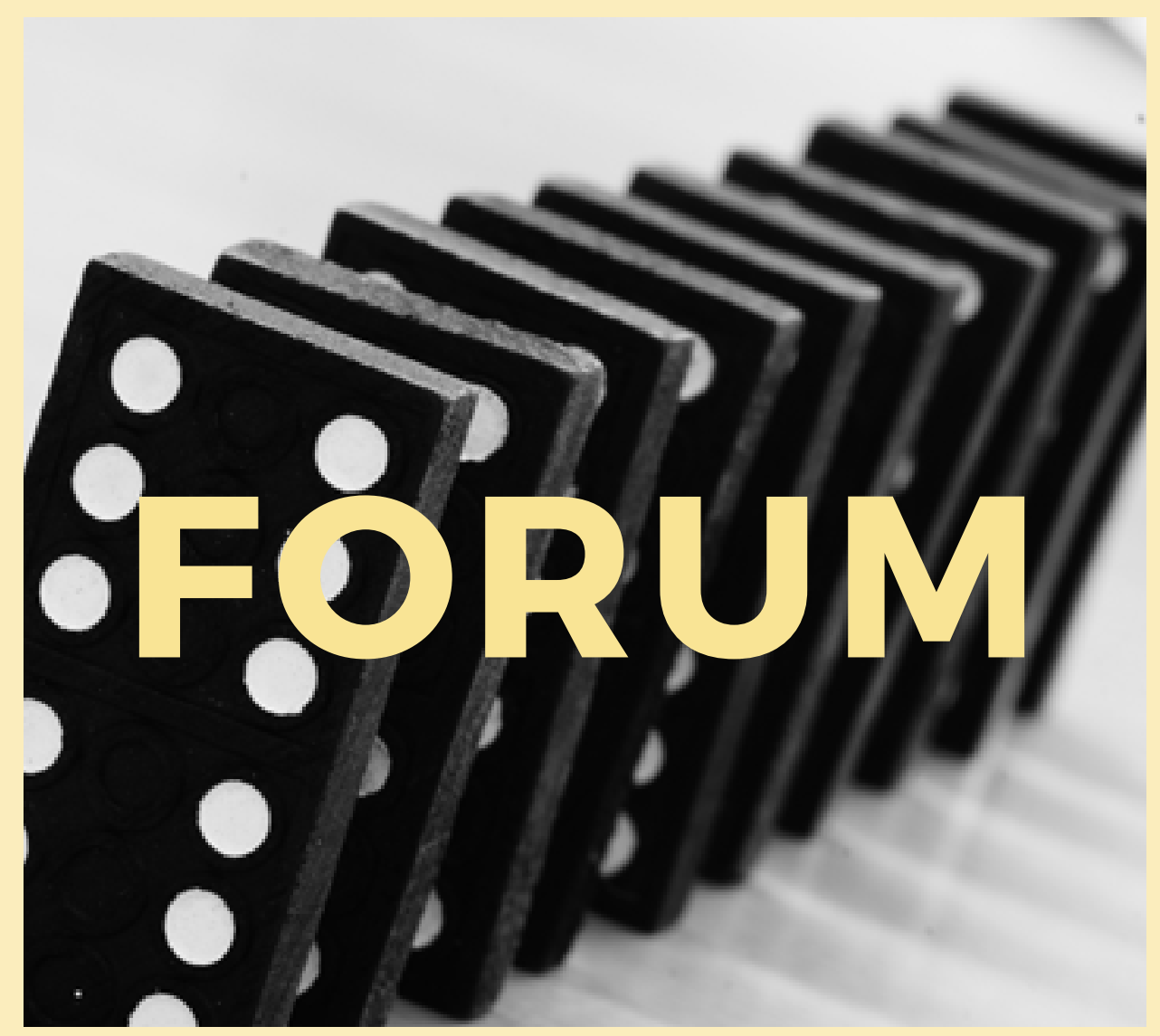

\section{Interpreting Chinese Labour: Informalisation or Empowerment?}

Edited by Ivan Franceschini and Kevin Lin

With the participation of

Kaxton Siu

Sarah Swider

Anita Chan 

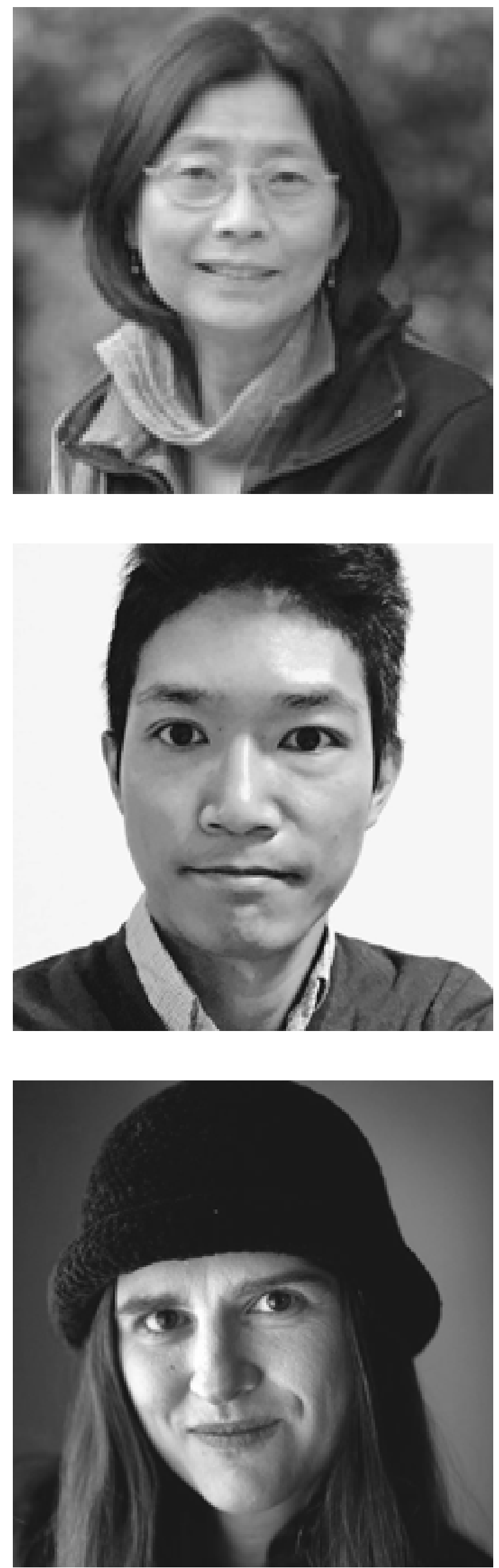

\section{Anita Chan}

Anita is Visiting Fellow at the Political and Social Change Department, The Australian National University. Prior to that, she was Research Professor at the University of Technology Sydney. Her current research focuses on Chinese labour issues. She has published widely on Chinese workers' conditions, the Chinese trade union, and labour rights issues.

\section{Kaxton Siu}

Kaxton is an Assistant Professor in the Department of Applied Social Sciences at Hong Kong Polytechnic University. His research concentrates on globalisation, labour, youth, social movements, and the political economy of development in East and Southeast Asia, particularly China, Vietnam, and Hong Kong.

\section{Sarah Swider}

Sarah is an Associate Professor of Sociology at Wayne State University. Her research focuses on informal and precarious workers. She examines the employment relations that define informal and precarious work, how they organise and protest, and examines how these workers are reshaping workplaces and urban spaces. Her publications include an award-winning monograph entitled, Building China: Informal Work and the New Precariat (Cornell University Press, 2015). 


\title{
Interpreting Chinese Labour: Informalisation or Empowerment?
}

\author{
Edited by Ivan Franceschini and Kevin Lin
}

The struggle and activism of Chinese workers has been a topic of primary interest since the beginning of the reform era. Still, expectations have never been higher than in the past few years, with an unending stream of media articles and academic papers hailing the new-found rights awareness of Chinese workers-especially the so-called second generation of migrant workers-as a critical development with the potential to disrupt the very foundations of the Chinese industrial and political system. This narrative describes a boom in strikes, sees social media as a revolutionary mobilisation tool, and portrays younger workers as eager to fight for their rights. Amid the euphoria, is such optimism warranted?

In fact, significant literature in both Chinese and English has argued that the discontinuity between the old and new generation of migrant workers has been exaggerated. However, these voices have been subsumed under the catchier narrative. In a recent article, Ching Kwan Lee has critiqued the work of fellow labour scholars for adopting an excessively optimistic view of labour activism in China. In particular, Lee has identified and challenged four claims advanced by the supporters of what she calls the 'empowerment thesis': the idea that Chinese workers are increasingly active and motivated to mobilise; the assertion that the new generation of migrant workers is more class and rights conscious than the first; the alleged maturation and radicalisation of labour activism, with workers' demands changing from defensive to offensive; and the claim that consistent increases in wages in China should be considered as evidence of workers' effectiveness and empowerment.

Arguing that such claims have scarce factual basis and that they overlook structures of inequality and power imbalances that lead to precarity, she launched an appeal to her peers: 'In this day and age of global precarisation, it has become ever more important that labour scholars, of China or elsewhere, resist the temptation of subjectivism and voluntarism, and recall Gramsci's famous motto: pessimism of the intellect and optimism of the will'. Heeding this advice-and in order to gain a better understanding of precarity and its effects on the Chinese workforce-we have invited three labour scholars who have researched precarious labour in its various manifestations in the Chinese labour market to offer some insights based on their experience in the field. 
What form has precarity and informal labour taken in the industries that you have researched, and what effects has it produced in the labour force?

Kaxton Siu: Over the past decade, I have been researching Chinese workers in toy, garments, electronics, and sanitary industries. Some of them work inside factories, while others, like street cleaners, work out in the open. The forms of precarity and informality, as well as their impact, differ from one industry to another. For workers in factories, major forms of precarity are still in the domain of working conditions, such as excessively long working hours, unpaid overtime, low wages, wage arrears, and occupational hazards. As for workers in the service industry such as street cleaners, most of them do not have stable jobs. Many of them just engage in irregular casual work, become part-timers, do not have regular working schedules, and receive very low wages, etc.

Sarah Swider: My research has mostly focussed on the construction industry, which is characterised by a bifurcated workforce. Most professional, managerial, and administrative jobs are full-time, stable, include benefits, and are filled by urban workers. In contrast, field positions, which are on jobsites, are mostly informal jobs filled by peasant workers from the rural areas who face precarity in their work and lives in the cities. They work under several different kinds of employment configurations, which shapes their precarity and vulnerabilities. I have documented three prominent employment configurations in this industry: mediated, embedded, and individualised. Many peasant-workers toil under mediated employment, named this way because their employment relationship is mediated by middlemen; usually large contractors who bring them into the city, house them, feed them, and pay them only at the end of year-long (informal) contracts. Others work in embedded employment, using social networks to find work, which embeds their work into these social networks, and in turn regulates the employment relationship. Finally, some workers toil in individualised employment. These jobs are found through street markets, and employment relations are highly despotic as unrestrained employers use violence, or the threat of violence, to deal with workers. These varied arrangements of precarious and informal work capture the increased fragmentation that makes it difficult to build solidarity. However, as informal workers, they tend to engage in struggles for recognition as workers and/or as citizens rather than struggles for increases in wages, benefits, and traditional worker/union demands. In general, formal precarious workers engage in struggles to increase wages; informal precarious workers engage in struggles to get paid at all. Formal precarious workers struggle for better benefits and representation; informal workers must struggle to be recognised as workers, and therefore, to be deserving of benefits.

Anita Chan: Many scholars have focussed their attention on industrial relations in the labour-intensive export sector in South China, but there have been few studies of capital-intensive industries such as the automotive industry. Back in 2011, I carried out a questionnaire survey with several hundred workers from five auto-assembly plants-note, not auto-supplier plants-all joint ventures with German, American, and Japanese partners. To my surprise, I found that the disparity between regular workers and agency workers is not big; in fact, it is remarkably small. For instance, not only the difference in length of contracts between the two groups tended to be small, but also the gap in their take-home wage was relatively little, with agency workers receiving on average 80.8 percent of the salary of their regular peers. The gap was further mitigated through annual bonuses. There was also no significant difference in work hours-both categories worked 
around nine and a half hours a day-and, even more importantly, all of them maintained almost the same neutral to positive attitudes towards management. The only significant difference concerned union membership: while sixty-eight percent of the regular workers were members of the company union, only 28.4 percent of the agency workers declared themselves as being union members. The reason behind this is that, from a managerial perspective, satisfying workers' material needs and keeping a stable and motivated workforce are of paramount importance in this industry. For this reason, agency workers have to be made to feel that they are having a fair if not equal deal compared to regular workers. And, let's be honest, companies can easily afford this!

\section{Alongside reports of precarious labour conditions, in the past decade a notable shift in the narrative of Chinese labour has occurred. While in the past Chinese workers were often described as being 'under assault' by their employers and the forces of globalisation, now there is much emphasis on their so-called 'rights awakening', especially among the young- est generation of migrants. Looking at the sectors you research from a long-term perspective, do you think that workers' consciousness has changed significant- ly? And, does workers' consciousness and agency play a measurable role in shaping their labour conditions today?}

Kaxton Siu: In recent years, much research has been done on the collective actions of Chinese workers and the impact of such mobilisations on workplace labour conditions, as well as on the responses of the Chinese state (for instance, experiments of types of collective consultation). However, from a long-term perspective, it seems that the discourses about the younger generation of migrant workers and Chinese workers' 'rights awakening' have been overstated. On the one hand, it has been seen that the sud- den rise of Chinese workers, witnessed for instance during the famous Honda strike of the summer of 2010, could not be sustained and turned into a significant political force influencing the labour policy of the Chinese government. On the other, various initiatives of the Chinese state, such as various 'collective consultation' experiments in different localities, diverged in their outcomes. Particularly, in some industries-such as the sanitary industry-where workers are more informal and precarious in terms of their working conditions and workplace bargaining power vis-à-vis employers, these official initiatives still cannot improve the livelihoods of vulnerable workers. As for workers' consciousness, despite what I mentioned above, from a long-term perspective, we indeed have witnessed some development of working-class consciousness among Chinese workers over the past twenty years. As many studies and factory ethnographies have documented, in the early 1990s, not only did Chinese migrant workers lack any sense of class consciousness; they also had a very fatalistic outlook. Their migrant worker identity, especially for young female migrant workers (dagongmei), was primarily constructed as an outcome of particular socio-economic and institutional structures, namely: the Chinese household registration system, the Chinese patriarchal structure, and the managerial domination by foreign capital inside factory workplaces. However, since the mid 2000s, we have seen some strike cases that demonstrate significant development in workers' consciousness. Not only have workers started to demand wages above the legal minimum, but workers have also started to organise themselves with fighting spirit and solidarity in the face of massive police suppression and violence. That being said, the majority of present-day Chinese migrant workers are still waging isolated uncoordinated rights-based protests and strikes. Only a few have gone beyond rights-based demands to an interest-based level in re- 
questing more than what is stipulated in current Chinese labour law. Only very few Chinese migrant workers are conscious enough to ask for setting up or re-electing workplace trade unions, or to organise strikes beyond individual factories at regional and country-wide levels.

Sarah Swider: This narrative of Chinese labour has been largely based on the experience of manufacturing workers. The number of factory workers who are still working under secure 'iron-rice bowl' conditions established under state socialism is dwindling. At the same time, there is an increasing number of peasants that have left the fields, but kept their land, and entered the factory to become "peasant-workers'. These two groups have very different social positions within society, different relationships to land and capital, and both are changing. As such, for each group a different worker consciousness emerges under marketisation. This is coupled with a generational shift characterised by younger workers who only have experience with state-led capitalism. However, construction workers are quite different. The construction industry has always relied heavily on peasant workers. These peasants were disadvantaged under the state-socialist system of the past, excluded from partaking in the iron rice bowl'. Today, under marketisation, they play an important role in urbanisation, but they are still disadvantaged, excluded from the benefits of urbanity and modernity. In other words, there has been no shift in their social position or their relations to land and capital. However, their changing environment does have an affect on them, and this is leading to a shift in worker subjectivity. Despite their continued connection to the land, many of these migrants are now spending most of their lives in the cities, which in many cases exposes them to other workers and protests. Thus, the paths that they imagine are possible, the number of potential avenues of protest, and the targets and the goals of the protests have grown and changed over time. Protests among construction workers, especially those focussed on wage arrears, are likely to be 'public drama protests' in which workers use drama to gain attention from the public, local and state officials, and other employers in the contracting chain to apply pressure so that they get their wages paid. These protests are usually collective actions, they are dramatic and creative so as to draw attention, and while they may publicly blame the contractors, they often indirectly target the state-owned enterprises (SOEs) or the companies further up the contracting chain, depending on the money flows. These protests are often successful because: a) they are sporadic so the government cannot predict or prevent these actions; b) they gain attention from the public and media that increases the costs of squashing the protests; and c) they garner symbolic power rather than power from disruption, which is more likely to gain support from different groups.

Anita Chan: Some scholars believe that agency workers and student interns in the automotive industry in China are second-class industrial citizens who harbour deep grievances due to this discrimination. In their opinion, this engenders labour activism. Personally, I think that this is an overstatement. Through my research, I found that the treatment these agency workers receive and their attitudes and aspirations are not decidedly different from regular workers, and certainly do not provoke a sense of injustice and anger. After all, for a whole decade since the mid-2000s there has been no big protest in China's auto assembly plants. My survey points to an overwhelming unwillingness to seek collective representation, less still to take militant action. For instance, when I asked the workers how would they solve a grievance, 44.9 percent of agency workers and 49.2 percent of regular workers said that they would go to their supervisor; 24.7 of agency work- 
ers and 21.3 percent of regular workers said that they would not ask anyone; and 13.6 of agency workers and 13.3 percent of regular workers said that they would just look for another job. Only 4.4 percent expressed a choice that entailed publicising their grievances beyond the workplace and soliciting external help, with as little as 0.4 percent of the respondents willing to go on strike. On the contrary, I found that both groups of workers were quite responsive to the paternalism of the company, with seventy percent of the agency workers and a slightly higher percentage of regular workers feeling let down if they did not receive festive gifts or money through the union or management. We also have to take into account the fact that compensation in the automotive industry is relatively high-in the companies in my survey the average basic wage was about double the local legal minimum wage and the take-home pay for both types of workers ranged from two to four times that of the local minimum wage.

Since the early 1990s the Chinese authorities have been adopting an increasingly complex body of labour laws and regulations, much of it quite favourable to workers. Is this turn to the law a sign of a genuine commitment by the authorities to protect worker rights against precarity? Have the Chinese labour laws limited or fostered precarisation?

Kaxton Siu: The 1994 Labour Law was the first comprehensive labour legislation passed in China since the founding of the People's Republic. The passage of the law stirred up a debate among government bureaucracies. At that time, the All-China Federation of Trade Unions (ACFTU) fought to ensure that the spirit of the law was advantageous to workers. However, the law did induce a change in workers' awareness, and migrant workers in the Guangdong region gradually began to use the law as an instrument to 'protect rights' (weiquan). Note that these rights refer to legal rights and not to inalienable human rights. The social discourse on 'rights protection' entails acceptance of prevailing laws as the standard by which work conditions and wages should be set. With the passage of the 1994 Labour Law, many Hong Kong labour NGOs, usually staffed by a few people, began setting up offices across the border, mostly in Shenzhen. These organisations played a significant role in popularising the idea of 'rights protection' among Chinese migrant workers in the area. Their programme focused on raising awareness among migrant workers of the details of the Labour Law and other regulations related to workplace health and safety. They taught migrant workers how to read their pay slips and pointed out where the payment and work hours fell short of legal requirements. They helped injured workers to seek compensation, which requires an expert understanding of how to assess grades of injuries and litigation procedures. Their persistence paid off within the space of a decade. Most migrant workers today in this part of China know about the legal maximum overtime, about the region's official minimum wage, and about industrial injuries compensation. Taking bosses to court for underpaying, going to the authorities to lodge legal claims for back pay, and suing for compensation for workplace accidents have become commonplace. Litigation is a legitimate form of protest. From a historical perspective, the passage of various labour regulations by the Chinese government has had positive impacts in protecting workers against further precarisation. However, we should note that the 1994 Labour Law was passed not because workers had been collectively making demands on the government, but because there was a consensus within the political elite that social stability had to be maintained by having a law to regulate industrial relations.

Sarah Swider: The law is contradictory in nature. In the process of defining 'work- 
ers', it leaves many out of the category; in the process of carving out protections, it creates unprotected activities and spaces; in defining some actions and activities as legal, it makes others illegal. Furthermore, the law is often intentionally ambiguous, leaving it to local and national leaders to interpret. Finally, laws and interpretations are only as good as the enforcement, which requires a different set of institutions and resources than those required to make laws. Thus, laws are not an adequate tool for limiting precarisation or limiting worker vulnerability, and this holds true across different national contexts. However, the multitude of complex labour laws that have been instituted in China still matters for workers. In some instances, the laws have become another tool in a worker's arsenal to deal with industrial conflict, and in other cases, the laws hold symbolic power, sending a message to local-level government and international capital to pull back on exploitation. In sum, laws make a difference but sometimes in unexpected and/or complex ways.

Anita Chan: There is indeed a problem of implementation, as the law has substantially failed to control the growing number of agency workers and abusive work practices. While not all auto assembly plants use agency workers-for instance BYD and Hyundai in Beijing do not-the five joint ventures in my sample do, even for up to half of their workforce. But the length of contracts of the two types of workers are both short. The average length of contracts for regular workers was about three years, whereas for agency workers it was about two years. There is a chance for agency workers to become regular workers, and regular workers having signed two short contracts can get a permanent contract, but this is quite rare. In this sense, even regular workers' employment is quite precarious. They are aware that in times of recession, they may be laid off as well. If we consider that these com- panies are all joint ventures in which one of the partners is an SOE at the provincial or city-level, it may appear paradoxical. But in reality the SOEs are the ones that employ the largest number of agency workers. There is a historical legacy to this. In the late 1990s, when millions of state workers were laid off, SOEs were required to set up employment agencies to find work for the laid-off workers. When it was discovered that agency workers can serve as buffers to the vagaries of the market, they were used in a big way, and they still are.

What is your assessment of the field of Chinese labour studies today, in China as well as abroad? In your opinion, is there any empirical and/or analytical gap that still needs to be filled and what should be done to address it?

Kaxton Siu: Due to the rise of China as a global powerhouse over the past twenty years, there is a great wealth of research about Chinese labour today. However, there is a tendency to consider the development of China and the making and remaking of the Chinese working class over the past decades as unique and exceptional. But is the Chinese experience really that exceptional? To answer this question, we should compare China to other similar socialist countries, such as Vietnam. Unfortunately, not much research has been done to compare labour conditions, industrial actions, trade union reforms, as well as modes, sequencing, and trajectories of economic reform in China and these countries. Another empirical gap is related to the recent household registration reform and the parallel change in the urbanisation process happening in China. Since the mid-2000s, a growing number of migrant workers have moved with their spouses and children from the countryside to industrial cities. In 2014, this phenomenal shift in migration patterns has led the Chinese government to reform their household registration systems. Now, thanks to 
the reform, it is said that it is easier for migrant workers to stay in the urban areas where they work. There, they are encountering new modes of housing arrangements, new forms of community relations, integration into new social networks in cities, and new household organisation strategies. Exactly how this process of integration happens and how the mobility of the families of migrant workers affects workers' outlooks on their working and family lives are worthwhile topics for further research. Yet these major shifts have barely been studied, nor has there been research done on how the new surge in married migrant couples with children affects labour relations inside the factories.

Sarah Swider: In China, some of the most interesting labour questions are about the relationship between labour politics and regime stability, especially given the significant rise in labour protests in the last few decades. Authoritarian regimes are generally believed to be unable to tolerate political mobilisation and protest, but China's variant of authoritarianism has encouraged, and sometimes stimulated and directed it. Some studies suggest that China's regime longevity has been because of, not despite, social protests, as it contributes to legitimacy, creates a carefully managed outlet for anger, and shapes and exploits cleavages among groups. This compels us to ask, under what conditions is this less likely to happen? What segments of labour are more difficult to control or more likely to push the boundaries? What issues or subjectivities are more likely to allow groups to overcome cleavages and fragmentation, and what forms of organising and protest are less likely to be controlled/co-opted? More generally, the rise of precarious work and the persistence of informal work across the globe means that most of the world's workers are beyond the formal economy and outside of state welfare and protections. We need a new paradigm to understand this reality and it will require us to rethink the relationships between the state and the economy, between production and redistribution, and between the productive and reproductive spheres; all of which might prove to be fertile ground for reimagining work, labour politics, and the future(s) of workers.

Anita Chan: In the past couple of decades, Chinese labour studies outside China have expanded rapidly, from only a handful of scholars working on the issue to a few dozen. However, there is an over-concentration on the study of migrant labour, with an overwhelming focus on Guangdong province. This imbalance has led to an excessive emphasis on labour resistance because a disproportionately large percentage of labour protests have been taking place in the South. In my view, it is time that we begin to branch out to explore new areas, new sectors, and new locations where labour protests are not that prevalent. In the instances where we find that workers in different places are more compliant, then it would be our task to explain why. 


\section{WORK OF ARTS}
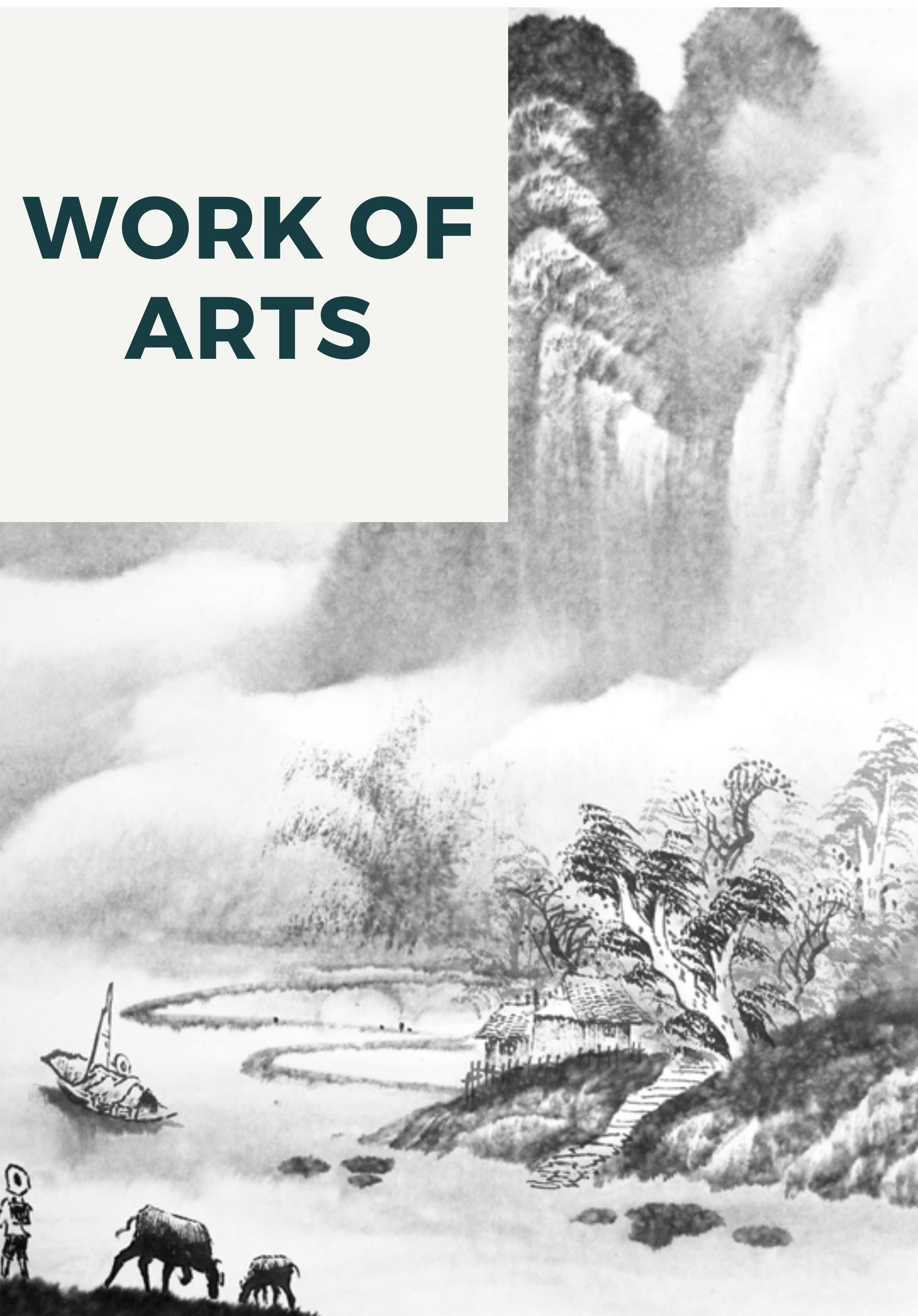


\section{The Cow and the Goat Descend the Mountain: Fighting Modernity with Poems}

\section{Ivan Franceschini}

A few years ago-it must have been towards the end of 2010-a big crowd had gathered in a loft in the Centre of Contemporary Arts in Shenzhen to enjoy the music of blind folk singer Zhou Yunpeng, an artist famous for his socially committed songs on issues such as child abuse, unemployment, sky-rocketing housing costs, and much more. Halfway through the concert, Zhou announced: 'Contemporaneity is helpless, antiquity will now make its entrance.' Then time seemed to stop, while a flow of words from poets of different ages and places started chasing each other, softly accompanied by the music of Zhou's guitar. Voices from the Tang era engaged in a lively conversation with bards from the Song and Qing ages. People who lived centuries apart borrowed Zhou's voice to express exactly the same feeling: an acute longing for their families and their hometowns.

Zhou was performing songs from his then recently-released album, The Cow and the Goat Descend the Mountain (niuyang xiashan), a collection of ancient Chinese poetry set to music which appeals to a dimension of human life that transcends time and space. Listening to the lines of $\mathrm{Du} \mathrm{Fu}(712-770)$ 'it is almost as hard for friends to meet as for the morning and evening stars' (ren sheng bu xiang jian, dong ru shen yu shang), or to Meng Jiao (751-814) lyrically describing how 'the thread in the hands of a fond-hearted mother makes clothes for the body of her wayward boy; carefully she sews and thoroughly she mends, dreading the delays that will keep him late from home' (ci mu shou zhong xian, you zi shen shang yi; lin xing mi mi feng, yi kong chi chi gui),

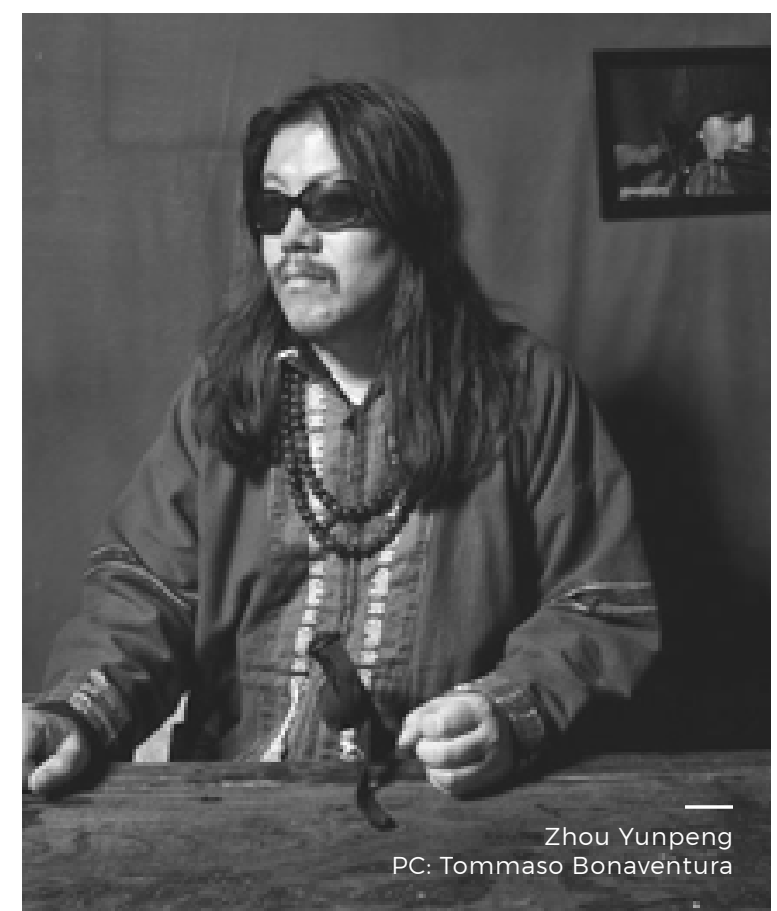

it is easy to forget that such words were written centuries ago. The same happens with Li Bai (701-762) and his poem 'The Moon over the Fortified Pass' (guanshanyue), which recounts how soldiers marching through the Jade Gate under the moonlight 'turn round, looking toward the border, and think of home, with wistful eyes and of those tonight in the upper chambers who toss and sigh and cannot rest' (shu ke wang bian se, si gui duo ku yan; lou dang ci ye, tan xi wei ying xian), or with the soldier in a poem by Nalan Xingde's (1655-1685), who dreams of his peaceful home while encamped on a river bank during a snowstorm.

\section{Two Faces of Nostalgia}

The recurrence of these feelings of detachment and homesickness all through 
Niuyang xiashan is unsurprising, since nostalgia is everywhere to be found in Chinese traditional poetry. As James Liu explained in The Art of Chinese Poetry, Chinese poets seem to be perpetually bewailing their exile and longing to return home, a feature that he attributes to

the vastness of China, the difficulties of communication that existed, the sharp contrast between the highly cultured life in the main cities and the harsh conditions in the remoter regions of the country, and the importance of the family in traditional Chinese society with the consequent deep attachment to the ancestral home. Moreover, being an agricultural people and a nation of landlubbers, the Chinese as a whole are noticeably lacking in Wanderlust.

But why sing these poems today, when distances in China, as elsewhere, have been dramatically shortened by improved communications? The simple answer is that this nostalgia is now more present than ever in the life of the Chinese people. Today's China is still a country of people on the move. Farmers leave the countryside to look for jobs in urban areas, students move to bigger cities to gain access to a better education, merchants travel from town to town to pursue their businesses. Families often have no other choice than to split up: rural mothers leave their children behind in the villages-husbands, wives and sons live and work in completely different places. Most of them meet no more than once a year, during the Spring Festival. Once they were soldiers and exiled poets, now they are migrant workers, students, and businessmen. Their existence may appear less poetic, but the underlying feelings do not seem to have changed.

Chinese language has two different words to express the concept of "nostalgia': on the one hand, huaijiu, literally 'embracing the old'; on the other, sixiang, 'homesickness'. Yet, as Niuyang xiashan clearly demonstrates, these expressions are both sides of the same coin. Singing those ancient poems, Zhou Yunpeng recounts stories of a long lost bucolic idyll mixed with melancholic feelings of nostalgia for a distant hometown. The title of the album itself is an allusion that exudes sadness and nostalgia-'the cow and the goat descend the mountain' paraphrases a verse from 'The Gentleman Serves in the Army' (junzi yuyi), a poem in the Classic of Poetry (shijing) about the wailing wife of a soldier far away from home. In the evening, the family's chickens are back in the henhouse, a yellow dog is sitting on the doorstep, even the cow and goat have come down from the mountain where they were grazing, only the husband is nowhere to be seen.

\section{Reminiscences from a Golden Age}

Ancient poetry is very much alive in today's China. As Bill Porter writes in Finding Them Gone, a recent book about his pilgrimages to the graves of the greatest poets of Chinese antiquity:

The graves of the poets I'd been visiting were so different. Some were simple, some palatial, some had been plowed under by farmers, and others had been reduced to trash pits. Their poems, though, had survived. They were still fresh in the minds of cigar-smoking farmers who most likely never attended high school. The same couldn't be said for the pronouncements of the high and mighty. Poetry is transcendent. We carry it in our hearts and find it there when we have forgotten everything else.

This holds particularly true for the selection of poetry included in Niuyang xiashan. All the poems performed by Zhou on this album belong to the collective memory of the Chinese people, and they therefore strike a chord with a Chinese 
audience from all walks of life. In an interview that I had with him in April 2012, Zhou explained that all those verses are reminiscences from his own childhood in the 1970s, when he had to learn them by heart at school: 'These poems are among the most popular in China, they are like a souvenir in your backpack, an old photo. I have been in many places, I have lost many books, but these poems are always with me. When I am on the road or I am waiting for a car or a flight, I just go over them in my head. It is like a spiritual massage and in doing so my spirit becomes peaceful. I did not choose those poems, they just popped up in my mind, it was so natural.'

Zhou lost his sight when he was nine years old. In the following decades, in spite of all the hardships he was forced to endure, he became a tireless traveller and an insatiable reader. During our interview, he repeatedly used the verb 'to look' (kan) to describe his experiences on the road. Still, this 'looking' seems to go well beyond the realm of the sight he had lost, being more like an act of 'contemplation' (guanzhao). In Zhou's own words: 'Contemplating is more than looking, it means experiencing something with all your body and mind, with the optic nerve of your soul.' Zhou believes that poetry has a fundamental role in this kind of contemplation: 'Ancient poems are very visual. Every single poem has a lot of images of mountains, rivers, flowers, smokes, trees, and skies and this is very good for blind people. These verses give us another reality, a reality that can be seen through the eyes of people from other ages. Those are the skies and the water of the Tang Dynasty and through poetry we can experience that world.'

\section{An Escape from Modernity?}

After many years of producing music that dealt critically with the plights of contemporaneity, one cannot but wonder whether Niuyang xiashan represent Zhou's escape from the many hardships of contemporary society. However, this does not seem to be the case. According to Zhou, this album is not just a return to the past, since those ancient poems bear extraordinary resemblances to today's social issues. As examples, during our interview he quoted two series of poems by Du Fu: 'Three Functionaries' (san li) and 'Three Separations' (san bie). In the first series, Du Fu writes about local cadres who press-gang all the able-bodied men into the army until only an old lady remains at home, and then also force this woman to join the army as a cook. According to Zhou, this story recalls today's forced relocations. 'Three Separations' instead tells the stories of elderly people without any kind of social security, and therefore with nothing to lose. From Zhou's point of view, the similarity to the situation of many old people today is obvious.

Neither 'Three Functionaries' nor 'Three Separations' are included in Niuyang xiashan, but contemporaneity still makes a few explicit appearances in this album. The first one is in the middle of ' $\mathrm{A}$ Song of Spring' (chunge), a composition that contains lines from three different poems by Wumen Shenshi (1183-1260) and Liu Yuxi (772-842). After sketching a series of bucolic images, Zhou starts telling the story of Li Bai, who reportedly one day saved his friend Wang Lun from drowning in a river. All of a sudden, in the middle of the song, Zhou Yunpeng directly addresses Li Bai: 'Comrade Li Bai, being an old Communist Party member from the Tang dynasty, what were you thinking when you dived into the water to save Wang Lun?' And Li Bai answers with nonchalance, mixing plain language with pompous lines from one of his most famous poems: 'Ah, purple mists rose from the Incense Peak in the sun, that day it was very hot; cascading from atop three thousand feet adown, I went to the 
river to bathe. While I was in the water I picked up Wang Lun.' With this joke, originally inspired by a child he once met, Zhou candidly mocks the Party propaganda about Lei Feng and other 'miraculous' model workers.

The second appearance of the modern age occurs in the last song, 'Love Without Speaking' (bu hui shuo hua de aiqing). This song, the only one on the album entirely written by Zhou Yunpeng, opens with a couple of verses of ancient flavour-'You are tired of doing your embroidery, even the cow and the goat have come down from the mountain' (xiu hua xiu de lei le $b a$, niu yang ye xia shang lo)-then plunges into a love story full of hatred and regret. Zhou is particularly proud of this song, which he deems the best work he has ever done:

'Love Without Speaking' is not a kind of pastoral sadness; it is a story of urban anxiety, that kind of anxiety, struggle, and hate that prominently feature in the life of people today, in a world dominated by material desires. I think that a love without hate would be incomplete. This is not only a love song, it is more a song about life in general. For instance, you can, at the same time, love and hate Beijing: your relationship with a place, a person, a time always has this kind of mixture of love and hate.

\section{Ancient Poetry as Resistance}

And love and hate are what Zhou Yunpeng feels toward this age, with all its progress in the field of communications, which have weakened the bond between people and their homes; with the rapid expansion of the Internet, which has destroyed the pleasure of writing letters and appreciating the relationships with far away friends; and with the systematic destruction of significant parts of China's cultural heritage. In the face of all this, the choice to recover these fragments of ancient poetry and give them new life through music seems to be more an act of resistance than an escape. As Zhou puts it: 'In the contemporary world, nostalgia, distance, and homesickness are all luxuries which belong to a utopia. We can only experience them through the bodies of the people from ancient times. Their way of life has become an ideal, something that we can only find by accident but not seek out on purpose. That is the reason I love the people in Niuyang xiashan: they still can experience those feelings.'

The translations of the verses of Li Bai, Meng Jiao, and Du Fu quoted in the text are by Witter Bynner.

\section{Ivan Franceschini}

Ivan Franceschini is a Marie Curie Fellow at Ca' Foscari University of Venice and at the Australian Centre on China in the World working on a project on Chinese labour in global perspective. From 2006 to 2015 , he lived in China, where he worked as a journalist and as a consultant in the field of development cooperation. His research interests focus on Chinese labour and civil society. 


\section{ACADEMIC WATCH}

\section{Mingwei Liu on China at Work}

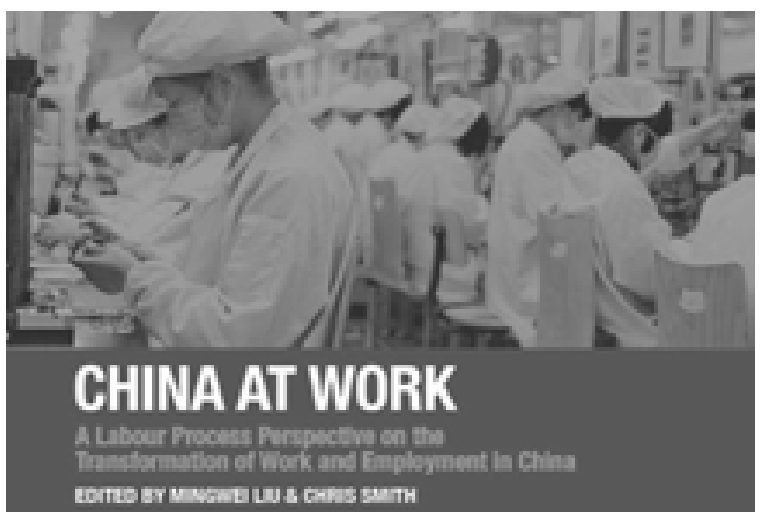

Edited by Mingwei Liu and Chris Smith, China at Work: A Labour Process Perspective on the Transformation of Work and Employment in China (Palgrave Macmillan, 2016) offers a series of perspectives on Chinese labour rooted in the empirical realities of a wide range of workplaces, from traditional state-owned enterprises to private garment factories, from Walmart stores to call centres. For our Academic Watch, we spoke with the book's co-editor Mingwei Liu, Associate Professor of Labour Studies and Employment Relations at Rutgers University.

In the introduction, you write that 'Chinese workers, employers, and local governments are much more diversified and the interactions and relationships among the three actors are much more complicated than the existing scholarship has revealed'. In your opinion, what is the best approach to render this complexity?

Mingwei Liu: While the fragmentation of workers, the state, and different types of employers is well recognised by China labour scholars, empirical research still lags behind in revealing the diversities of these actors. Existing research in the past decade focuses heavily on rural migrant workers in labour intensive manufacturing factories, on employers from East Asia, and on local states in coastal areas, particularly in Guangdong. Where variations are noted, they often focus on differences between urban and rural workers, between state-owned and foreign-invested enterprises, or between local states in coastal and inland areas. However, diversity results from a much wider range of factors, including occupations, industries, and specific local economic, social, and cultural factors. The best approach to understanding this diversity and complexity is to conduct extensive fieldwork. Yet, for any researcher, fieldwork is time consuming and access to the field is often difficult. Therefore, collective efforts are needed to build our knowledge. That was exactly one of our motivations to edit this volume.

Most chapters have been written by young academics from China. What are the theoretical traditions that have exerted the greatest influence on the work of this new generation of scholars?

ML: Yes, it is indeed a feature of this book that most contributors are young scholars from China. Having grown up in China in an era of rapid economic and social development, these young scholars may bring new perspectives to the field of Chinese labour studies. As for the theoretical frameworks, labour process theory is perhaps the most influential one. In particular, Michael Burawoy's work has greatly influenced the research of many young scholars, as can be seen from several chapters in our book that focus on power relations and dynamics on the shopfloor. A smaller group of young scholars, influenced by the pluralist perspective of industrial relations, focus their analysis on labour market institutions aiming to understand either how institutions 
affect work and employment or how workers and their interactions with other actors shape institutions. Several of them also contributed chapters to our book. In addition, a few young scholars take legal or political economy perspectives to study laws, public policies, and other macro level institutions, but as these perspectives are quite distant from labour process theory, we did not include them in our book.

A section of the book is devoted to discussing China's trade unions and collective bargaining. As a leading scholar on these topics, how do you assess the recent trends in union reforms and collective bargaining in China, and where do you think such trends are leading?

ML: In a forthcoming paper with Sarosh Kuruvilla, we summarise recent developments of trade unions and collective bargaining in China as 'the good, the bad, and the ugly'. The 'good' refers to some meaningful reforms and experiments of the All-China Federation of Trade Unions (ACFTU) at municipal, district, and town levels, such as direct elections of union chairs in Guangdong, local industry-level collective bargaining in Zhejiang and Jiangsu, more genuine collective bargaining after wildcat strikes, and the ongoing experiment on the professionalisation of union staff and grassroots organising and bargaining in Shenzhen. The 'bad' includes the great quantitative expansion of unions and collective bargaining without significant improvement in quality and the continued or even strengthened Party control over unions. The 'ugly' refers to the latest crackdown on labour NGOs and activists that assisted workers in their quest for genuine collective bargaining. All of these trends may continue in the near future. Without regime change, it would be very hard, if not impossible, to see the development of independent trade unions and collective bargaining in China. There is a possibility that the ACFTU might significantly improve its worker representative role at workplaces without gaining full autonomy from the Party. Yet, that would be a long shot.
The last section of the book forays into the under-researched realm of industrial relations in Chinese companies abroad. Are Chinese labour investments in other countries as threatening for labour standards as commonly believed?

ML: Again, Chinese overseas investments are diverse in terms of industries, ownership, and types of host countries. In general, both Chinese factors and local institutions and cultures determine their labour practices. Where labour regulations and unions are weak, such as in many African and Latin American countries, Chinese firms have more discretion in transferring Chinese labour practices, a situation which may possibly lower local labour standards. Yet, compared to labour practices in Western firms in these same countries, Chinese practices might not be significantly worse. Perhaps the most controversial labour practice of Chinese firms in these contexts is the heavy use of Chinese expatriates, not only as managers and technicians, but also as frontline workers. In many of these countries, Chinese firms circumvent regulations on the employment of foreign workers, and the protection of labour rights fundamentally depends on the local institutions and labour movements. But strengthening civil society monitoring will help to some extent. Where labour regulations are strict or unions are strong, for instance in the United States and many European countries, however, Chinese firms have been struggling to adapt their labour practices to local norms. This is particularly true in the United States, where Chinese firms face high 'liability of foreignness'. Perhaps the most complained about labour practices of Chinese firms in these countries are those related to discrimination, due largely to Chinese firms' insensitivity to gender, race, and other diversity issues. But this may not cause severe concerns given the strong regulations and/or unions in these contexts. 


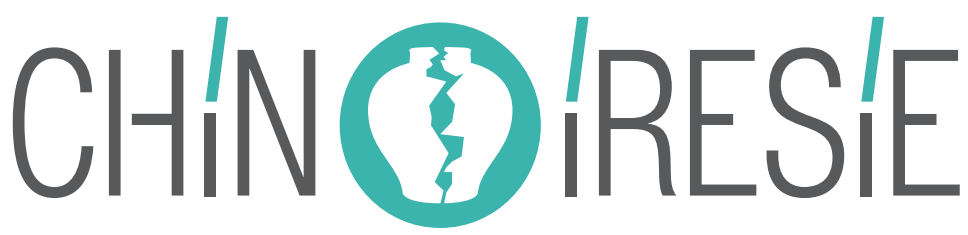

mismatched shards of China

No expertise comes without constant doubt and a willingness to challenge established truths. Chinoiresie.info is a new website that attempts to question some of today's understandings and certainties about China.

Follow us: Facebook | Twitter | RSS

\section{RECENT ESSAYS}

Jonathan Unger

Grassroots Turmoil in China's Cultural Revolution: A Half Century Perspective

[Read on Chinoiresie]

Gerda Wielander

Chinese Dreams of Happiness: What Are the Chances? [Read on Chinoiresie]

Gianluigi Negro

Internet Sovereignty and China: Beyond the Wuzhen Summit

[Read on Chinoiresie]

Tom Cliff

Oil and Water: Being Han in Xinjiang

[Read on Chinoiresie]

\section{TIANXIA PODCAST}

Tessa Morris-Suzuki: To the Diamond Mountains and Beyond

[Listen to this episode] 

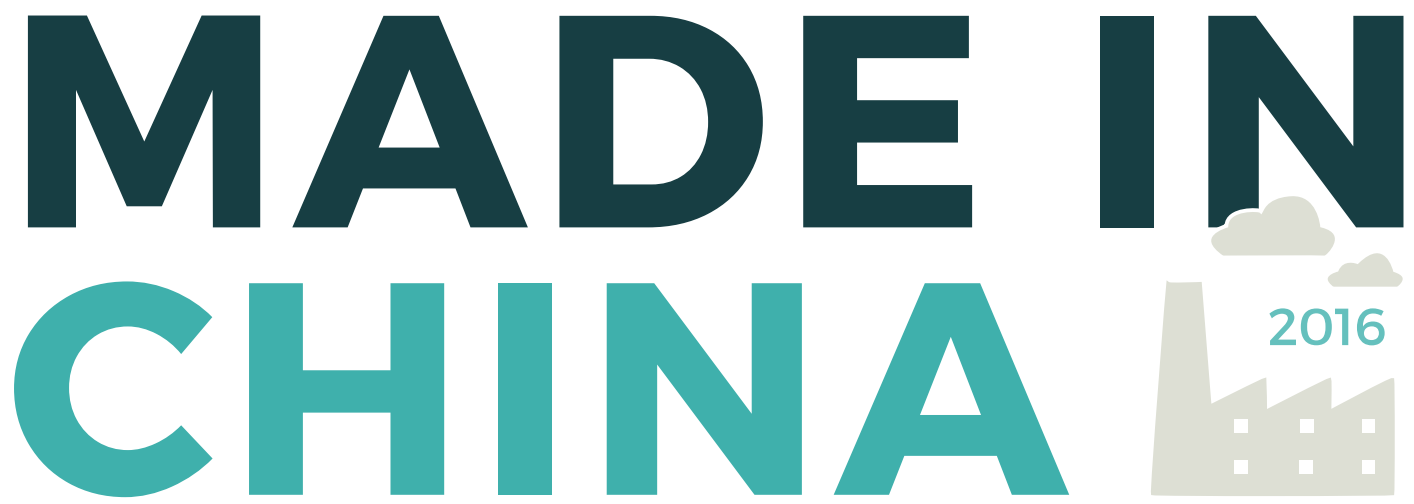

2016

A Quarterly on Chinese Labour, Civil Society, and Rights 